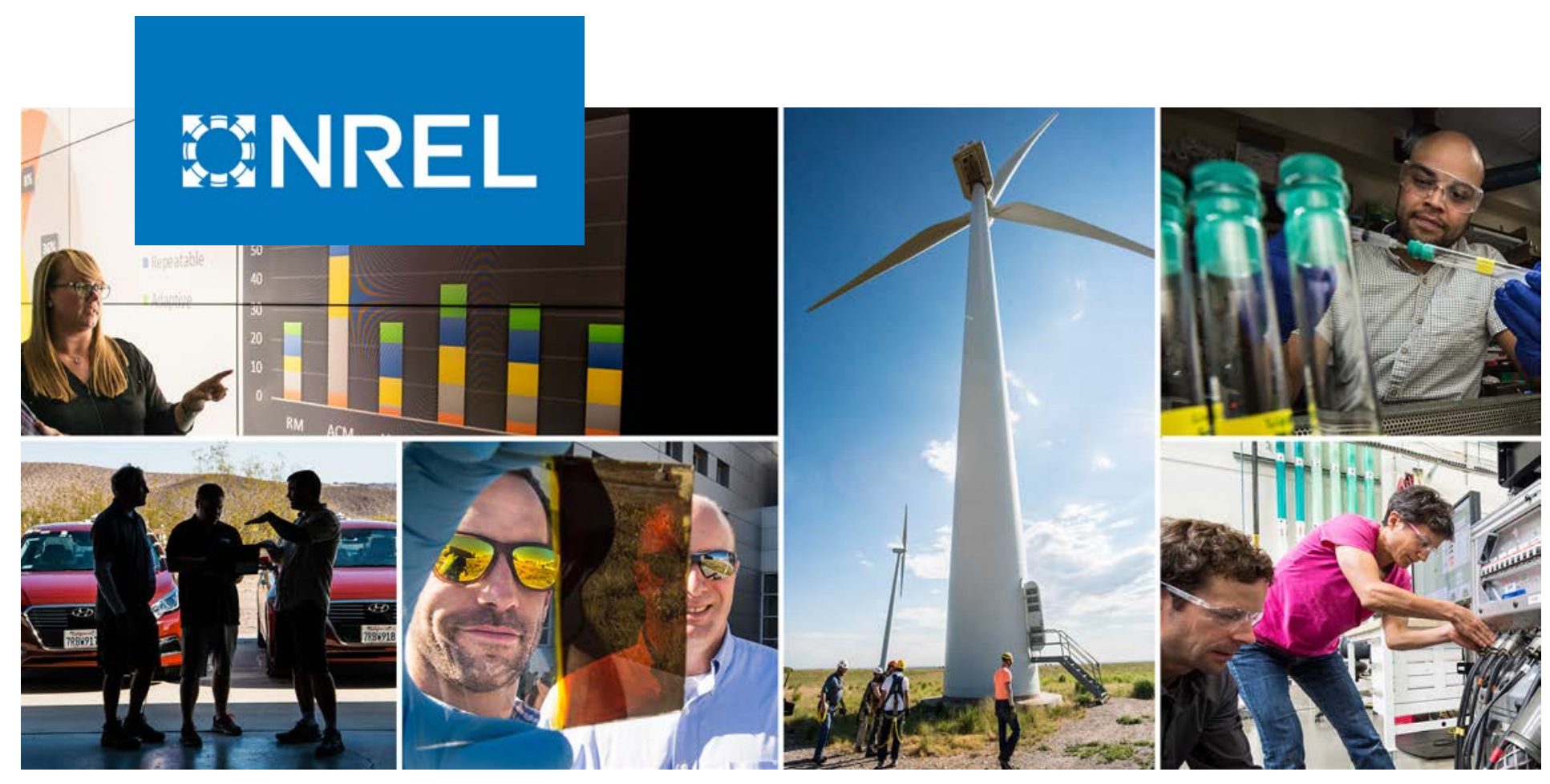

\title{
Sedimentary Geothermal Resources in Nevada, Utah, Colorado, and Texas
}

Henry Johnston, Amanda Kolker, Greg Rhodes, and Nicole Taverna

National Renewable Energy Laboratory

NREL is a national laboratory of the U.S. Department of Energy Office of Energy Efficiency \& Renewable Energy

Operated by the Alliance for Sustainable Energy, LLC

This report is available at no cost from the National Renewable Energy Laboratory (NREL) at www.nrel.gov/publications.
Technical Report

NREL/TP-5500-76513

August 2020 


\section{GNREL}

\section{Sedimentary Geothermal Resources in Nevada, Utah, Colorado, and Texas}

Henry Johnston, Amanda Kolker, Greg Rhodes, and Nicole Taverna

National Renewable Energy Laboratory

\section{Suggested Citation}

Johnston, Henry, Amanda Kolker, Greg Rhodes, and Nicole Taverna. 2020. Sedimentary Geothermal Resources in Nevada, Utah, Colorado, and Texas. Golden, CO: National Renewable Energy Laboratory. NREL/TP-5500-76513.

https://www.nrel.gov/docs/fy20osti/76513.pdf.

NREL is a national laboratory of the U.S. Department of Energy Office of Energy Efficiency \& Renewable Energy Operated by the Alliance for Sustainable Energy, LLC

This report is available at no cost from the National Renewable Energy Laboratory (NREL) at www.nrel.gov/publications.

Contract No. DE-AC36-08GO28308
Technical Report NREL/TP-5500-76513 August 2020

National Renewable Energy Laboratory 15013 Denver West Parkway Golden, CO 80401 303-275-3000 • www.nrel.gov 


\section{NOTICE}

This work was authored by the National Renewable Energy Laboratory, operated by Alliance for Sustainable Energy, LLC, for the U.S. Department of Energy (DOE) under Contract No. DE-AC36-08GO28308. Funding provided by the U.S. Department of Energy Office of Energy Efficiency and Renewable Energy Geothermal Technologies Office. The views expressed herein do not necessarily represent the views of the DOE or the U.S. Government.

This report is available at no cost from the National Renewable Energy Laboratory (NREL) at www.nrel.gov/publications.

U.S. Department of Energy (DOE) reports produced after 1991 and a growing number of pre-1991 documents are available free via www.OSTI.gov.

Cover Photos by Dennis Schroeder: (clockwise, left to right) NREL 51934, NREL 45897, NREL 42160, NREL 45891, NREL 48097, NREL 46526.

NREL prints on paper that contains recycled content. 


\section{Foreword}

This study was performed by staff working in the Geothermal Program at the National Renewable Energy Laboratory (NREL) in Golden, Colorado.

Henry Johnston is a reservoir engineer with over 30 years of professional experience in the oil and gas industry. Since joining NREL in 2015, Henry has worked on geothermal research and development projects involving enhanced geothermal systems, compressed gas energy storage (U.S. Patent No. 2020/0039749 A1, 2019), and advanced geothermal systems. His research interests include numerical simulation of fluid flow and heat transport in geothermal wells and fractured reservoirs.

Dr. Amanda Kolker is a geothermal energy researcher with over 10 years of professional experience as a geothermal geologist, specializing in resource exploration and sustainable production of geothermal energy. With a background in volcanology, igneous petrology, and geochemistry, Amanda has worked in academia, government, and private industry on geothermal research and development.

Greg Rhodes is a geothermal research analyst with experience in financial analysis, market research, and geologic and geophysical exploration studies aimed at reducing geothermal development costs and increasing deployment. Previously, he studied and developed geothermal systems for over 10 years in academia and private industry. His work included international field studies in countries including Honduras, Chile, Ethiopia, Indonesia, China, and Turkey.

Nicole Taverna is a member of both the Data, Analytics, Tools \& Applications and Geothermal groups at NREL. She has worked on a variety of projects, including updating and analyzing the impacts and uses of induced seismicity from enhanced geothermal systems (EGS) stimulations and constructing a geothermal drilling curriculum to be taught concurrently with an existing petroleum drilling curriculum at the Colorado School of Mines. 


\section{Preface}

This one-year study began with a literature review of past work on the feasibility of developing sedimentary reservoirs for geothermal energy production. The earliest publication reviewed was a 1978 U.S. Geological Survey assessment of geothermal resources in the United States that found immense quantities of thermal energy in multiple geologic environments, including sedimentary geothermal reservoirs (Muffler 1978).

Publications from the 1990s describe a geopressured-geothermal demonstration project at Pleasant Bayou, where brine in sedimentary reservoirs is saturated with natural gas. The site was at a location 40 miles south of Houston, Texas. The demonstration consisted of two wells and a 1-MW hybrid cycle power plant, which generated power for approximately one year (June 1989May 1990) using a binary cycle turbine and a gas engine.

Publications over the last decade describe sedimentary geothermal resources in Colorado, Louisiana, Nevada, Texas, Utah, and Wyoming. In this study, we assessed the relative attractiveness of these locations based on their reservoir temperatures $\left(150^{\circ} \mathrm{C}-200^{\circ} \mathrm{C}\right.$ or higher) at moderate depths $(3-4 \mathrm{~km})$ with adequate permeabilities $(10-100+$ millidarcies $)$ and sufficient thicknesses $(50-100+\mathrm{m})$. 


\section{Acknowledgments}

Funding for this study was provided by the U.S. Department of Energy Office of Energy Efficiency and Renewable Energy, Geothermal Technologies Office. 


\section{List of Acronyms}

AGS

BHT

advanced geothermal systems

CGS

DOE

bottom-hole temperature

carbonate geothermal system

EGS

U.S. Department of Energy

enhanced geothermal systems

GBCAAS

LCAU

LCOE

Great Basin carbonate and alluvial aquifer system

lower carbonate aquifer unit

levelized cost of energy

NETL

National Energy Technology Laboratory

NREL

PFA

UCAU

National Renewable Energy Laboratory

play fairway analysis

upper carbonate aquifer unit 


\section{Executive Summary}

The objectives of this project were to (1) perform a literature review of sedimentary geothermal resources, (2) identify data sources and develop data-collection methodologies that characterize selected resources, (3) screen sedimentary basins and formations for sedimentary geothermal potential, and (4) evaluate the technical feasibility of one or more selected locations.

Numerous publications have characterized geothermal resources within sedimentary basins. A literature search reviewed publications describing resources located in Colorado, Louisiana, Nevada, Texas, Utah, and Wyoming. The most attractive resources have high temperature gradients, low drilling costs, and reservoir permeabilities greater than 10 millidarcies $(\mathrm{mD})$. Prospects in Colorado, Nevada, Texas, and Utah exhibit attractive characteristics and were chosen for further analysis.

Sedimentary resources in Nevada and Utah are most attractive, followed by tested resources in Texas and untested resources in Colorado. The identified resources in Wyoming and Louisiana had lower geothermal gradients and were not evaluated. Reservoir modeling and technoeconomic analysis were performed at Marys River Basin-North in Nevada. Geothermal energy production at this location is expected to have a levelized cost of energy (LCOE) ranging between 10 and 20 cents/kWh. Additional work may result in lower LCOE estimates at this location and at other attractive prospects in these three regions.

The Great Basin carbonate and alluvial aquifer system of eastern Nevada and western Utah includes a lower carbonate aquifer unit, which has the potential for hosting both conduction- and convection-dominated geothermal systems. Mapping has identified lateral thickness variability expressed as a roughly 120-150-km-wide central corridor, which hosts the thickest and most continuous formations and extends from near Las Vegas north to the Idaho border. Purchase and analysis of privately held legacy seismic data could potentially compensate for the lack of sufficient data documenting measured depth to the lower carbonate aquifer unit. Multiple orogenies, extension episodes, and intrusive events have deformed and displaced the target formations of the lower carbonate aquifer unit. This structural complexity and potential for dipping reservoirs emphasizes the need for detailed geological, geophysical, and reservoir modeling.

Heat flow within three Colorado sedimentary basins reviewed as part of this study was calculated in targeted studies by the Colorado Geologic Survey and Colorado School of Mines. These calculations are based on bottom-hole temperature data sets with significant limitations and some variability but produce values consistently higher than the global continental average of 65 $\mathrm{mW} / \mathrm{m}^{2}$ for all three basins. Heat flow in the Raton Basin is the highest; however, permeability measurements from specific sedimentary formations with high heat flow have not been obtained.

Promising formations for sedimentary geothermal systems were found in all three regions studied-Nevada-Utah, Colorado, and Texas. The next steps for developing sedimentary geothermal resources vary due to differences in available data and resource uncertainties. Additional scopes of work are recommended for identified basins in these three regions. 


\section{Table of Contents}

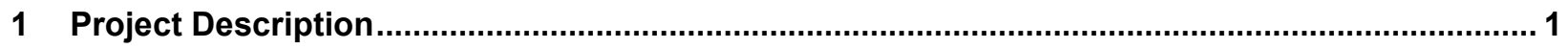

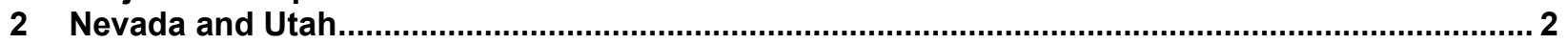

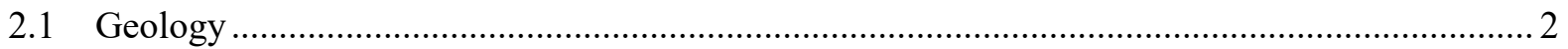

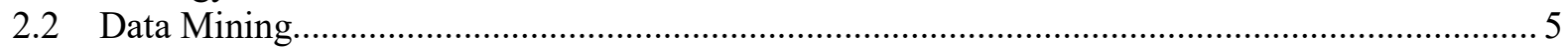

2.3 Area Selected for Reservoir and Techno-Economic Modeling ............................................... 10

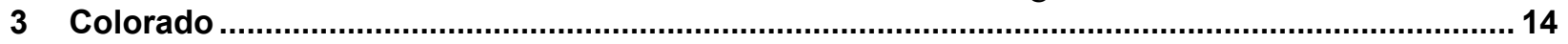

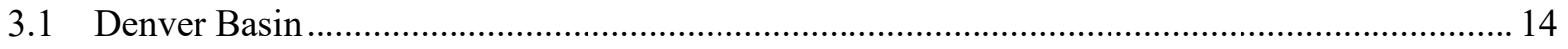

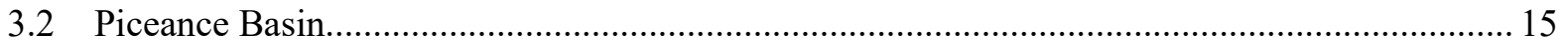

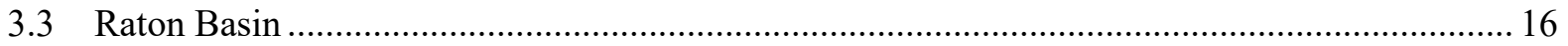

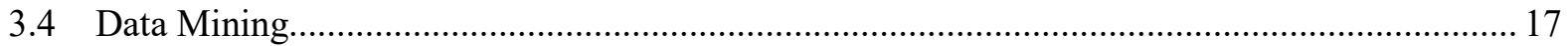

4 Texas

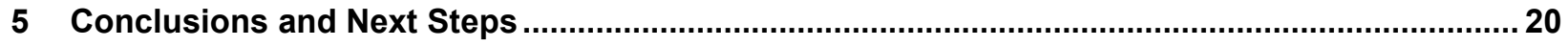

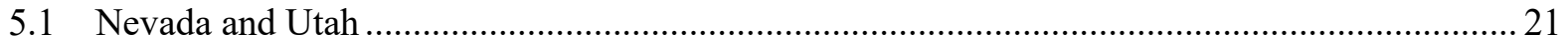

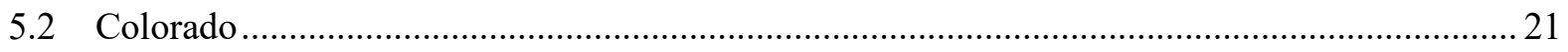

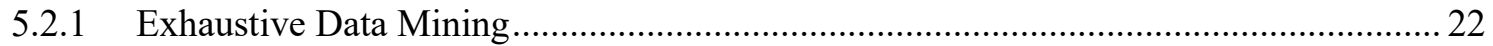

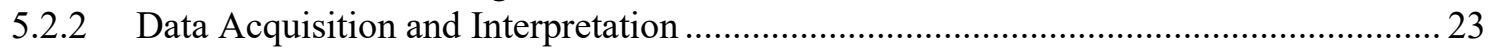

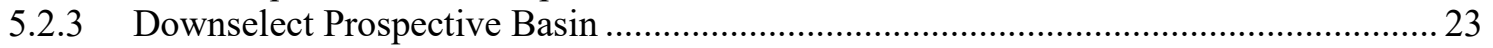

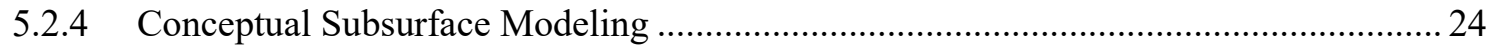

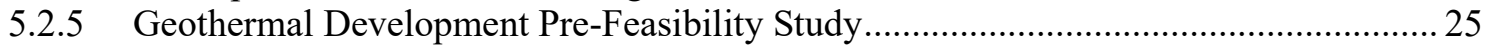

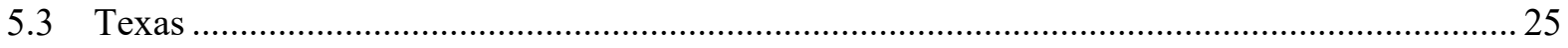

References 


\section{List of Figures}

Figure 1. Location of carbonate rock province (LCAU) within GBCAAS. The 120-150-km-wide corridor of thickest carbonate occupies the western half of the carbonate province ............................. 3

Figure 2. Conceptual model of geothermal evolution of the Grant Canyon and Bacon Flat oil reservoirs.. 5

Figure 3. Shaded relief map (feet above sea level) of the eastern Great Basin and western Colorado

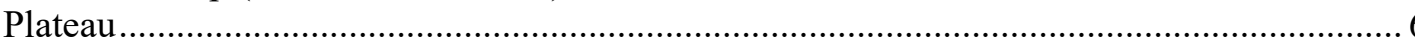

Figure 4. Plot of average bottom-hole temperature (BHT) versus depth linearly extrapolated to $4 \mathrm{~km}$ for wells in northeastern Nevada and western Utah. Data were pulled from oil and gas and geothermal well log databases

Figure 5. Plots of BHTs versus depth linearly extrapolated to $4 \mathrm{~km}$ for wells in basins with the highest temperatures: Marys River, Steptoe Valley, and Blackburn ................................................ 8

Figure 6. Plots of BHTs versus depth linearly extrapolated to $4 \mathrm{~km}$ for wells in the fields with isolated high-temperature anomalies: Bacon Flat and Pavant Butte .............................................. 9

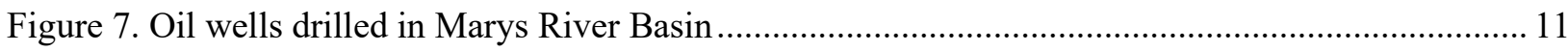

Figure 8. Reservoir layers and well locations in CMG STARS model.................................................. 12

Figure 9. Producer wellhead temperature profile when mass flow rate $=63 \mathrm{~kg} / \mathrm{s}$ per well .................... 12

Figure 10. Map of temperature gradient data for the Canon City Embayment, Hugoton Embayment, and North Park, Paradox, Piceance, Raton, and Sand Wash Basins. Calculated temperature gradients (Dixon 2004) are overlain on an interpretive temperature gradient map (Sares, Berkman, and Watteson 2009) for comparison............................................................... 18

Figure 11. Injection data from Raton Basin wells from the Colorado Oil and Gas Conservation Commission (19 wells with records back to January 1, 1999), plotted with average injection rate (gallons per minute), cumulative injection volume (barrels), and corrected bottom-hole temperature $\left({ }^{\circ} \mathrm{C}\right)$ from the Colorado Geological Survey....

Figure 12. Left Panel: Frio and Wilcox Fairways (Esposito and Augustine 2011). Right Panel: Structure map of Wilcox Formation within the Cuero Fault Block in the DeWitt Fairway (Bebout et al. 1982).

Figure 13. Schematic of combined binary cycle multi-effect distillation plant used to generate electricity and desalinate brackish groundwater. Generated electricity is used to power the system pumps.

\section{List of Tables}

Table 1. Wells That Have Not Been Plugged and May Be Evaluated for Deepening to Quantify Reservoir Properties

Table 2. Differences Between a Published Reservoir Model and the Model Used in This Study............. 11

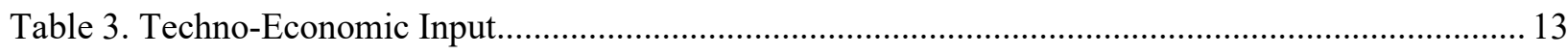

Table 4. Techno-Economic Results for Mass Flow Rate $=63$ kg/s Per Well and 50-Year Field Life ....... 13 


\section{Project Description}

Sedimentary geothermal resources consist of sedimentary rock formations located in basins usually associated with oil and gas production that have sufficient temperature and permeability to support production of commercial quantities of geothermal fluids. Sedimentary geothermal resources offer the opportunity to use existing petroleum industry data and technologies to development significant geothermal resources. Because of their large lateral extent, sedimentary formations may be capable of supporting geothermal projects that could be developed in a repeatable, scalable manner.

Producing geothermal energy from sedimentary basin settings may have several advantages over more conventional convection-based hydrothermal settings. Exploration time and expenditure could be shorter because prospects often have existing subsurface data sets from previous oil and gas exploration campaigns (Porro and Augustine 2012). Sedimentary geothermal reservoirs are also likely to have a greater areal extent $\left(>100 \mathrm{~km}^{2}\right)$ compared to the $<10-\mathrm{km}^{2}$ average for faultcontrolled hydrothermal reservoirs. Because heat flow in sedimentary reservoirs is dominated by conduction and not convection, and their geometry is more predictable, drilling risk is lower in terms of targeting the resource. On the other hand, the required resource temperatures are deeper than in hydrothermal upflow settings (Allis et al. 2011).

Allis et al. (2013) determined that geothermal energy production from sedimentary basin settings was feasible (levelized cost of energy $[\mathrm{LCOE}]<10$ cents/kWh) if the reservoirs met the following requirements:

- heat flow $>80 \mathrm{~mW} / \mathrm{m}^{2}$

- reservoir temperatures of $>175^{\circ} \mathrm{C}$

- depths $<4 \mathrm{~km}$.

Permeability requirements were not given, but it was noted that carbonates at required depths have an average permeability of $\sim 75$ millidarcies $(\mathrm{mD})$, with siliciclastic units averaging $\sim 30$ $\mathrm{mD}$. Augustine (2014) found that higher permeabilities (i.e., hundreds of millidarcies) were required for well doublet systems with useful lifetimes of multiple decades. The required permeabilities are at the high end of those found in sedimentary formations, especially at the depths where temperatures are typically high enough for electricity generation. Lowpermeability domains in sedimentary basins may represent enhanced geothermal systems (EGS); however, it is debatable if reservoir stimulation in tight sedimentary rock provides sufficient flow rates when natural fracture permeability is lacking (Tester et al. 2007). It may not be possible with current stimulation technologies to sufficiently generate distributed permeability in unfractured sedimentary rock.

The objectives of this project were to (1) perform a literature review of sedimentary geothermal resources, (2) identify data sources and develop data-collection methodologies that characterize selected resources, (3) screen sedimentary basins and formations for sedimentary geothermal potential, and (4) evaluate the technical feasibility of one or more selected locations. 
Numerous publications have characterized resources within sedimentary basins. A literature search reviewed publications describing resources located in Colorado, Louisiana, Nevada, Texas, Utah, and Wyoming. In this study, we assessed the relative attractiveness of these locations based on their reservoir temperatures $\left(150^{\circ} \mathrm{C}-200^{\circ} \mathrm{C}\right.$ or higher) at moderate depths $(3-$ $4 \mathrm{~km})$ with adequate permeabilities $(10-100+\mathrm{mD})$ and sufficient thicknesses $(50-100+\mathrm{m})$. The most attractive resources have high temperature gradients, low drilling costs, and reservoir permeabilities greater than $10 \mathrm{mD}$. The identified resources in Wyoming and Louisiana had lower geothermal gradients and were not evaluated. Prospects in Colorado, Nevada, Texas, and Utah exhibit attractive characteristics.

Resources in Nevada and Utah are discussed in Section 2, which includes regional geologic characterizations, mined data and analysis for multiple areas, and reservoir modeling and technoeconomics for one specific area of interest. Section 3 describes the regional geology of three sedimentary basins in Colorado, and one specific area of interest in Texas is discussed in Section 4. Section 5 lists potential next steps for further study in these three regions.

\section{Nevada and Utah}

\subsection{Geology}

The Great Basin carbonate and alluvial aquifer system (GBCAAS) of eastern Nevada and western Utah consists mostly of Cenozoic basin-fill and volcanics, Paleozoic carbonates with minor clastic interbeds, and Precambrian bedrock with some Mesozoic to Cenozoic magmatic intrusives and caldera extrusives unevenly distributed throughout (Heilweil and Brooks 2011). The Paleozoic carbonates, mostly limestone and dolomite deposited between the Cambrian and Devonian Periods, can be further subdivided into upper and lower carbonate aquifer units (UCAU and LCAU, respectively) (Masbruch, Heilweil, and Brooks 2012). Available literature and oil-well data suggest that the LCAU offers better potential for hosting both conduction- and convection-dominated geothermal systems due to both greater depth (typically $>2-3 \mathrm{~km}$ deep in basins, allowing for increased conductive heating) and thickness (LCAU surface exposures are often measured $>1 \mathrm{~km}$ thick, allowing for a larger potential reservoir volume) (Heilweil and Brooks 2011). Though the GBCAAS is quite extensive (Figure 1), mapping has identified lateral thickness variability expressed as a roughly 120-150-km-wide central corridor, which hosts the thickest and most continuous LCAU and extends from near Las Vegas north to the Idaho border (Dettinger et al. 1995). Identifying the buried formation tops of the LCAU throughout this corridor is currently difficult, as publicly available data are limited to interpretations of oil-well cuttings. These wells were typically not targeting the LCAU as a potential hydrocarbon reservoir, and thus rarely penetrate a substantial thickness of the LCAU. This lack of sufficient data documenting measured depth to the LCAU could potentially be resolved through purchase and analysis of privately held legacy seismic data.

The LCAU has also shown indications of higher permeability relative to the UCAU, demonstrated both by drill stem tests and by abundant sustained lost circulation zones during oilwell drilling. This high permeability should also be evident in equilibrated temperature gradient $\operatorname{logs}$, but few logs, if any, are available in oil-well records as these wells were not targeting a geothermal resource. Permeability likely results from a combination of primary depositional processes and secondary fracture, dissolution, and brecciation processes caused by numerous 
extension and intrusion episodes, karstification, and hydrothermal fluid circulation (Heilweil and Brooks 2011). As discussed below, hydrothermal fluid also has the potential to reduce permeability through mineral precipitation. High permeability in the shallower, colder basin-fill and carbonate units of the GBCAAS has resulted in abundant lateral groundwater flow, which has been hypothesized as a potential mask of shallow heat flow related to deep blind geothermal systems (Coolbaugh et al. 2005).

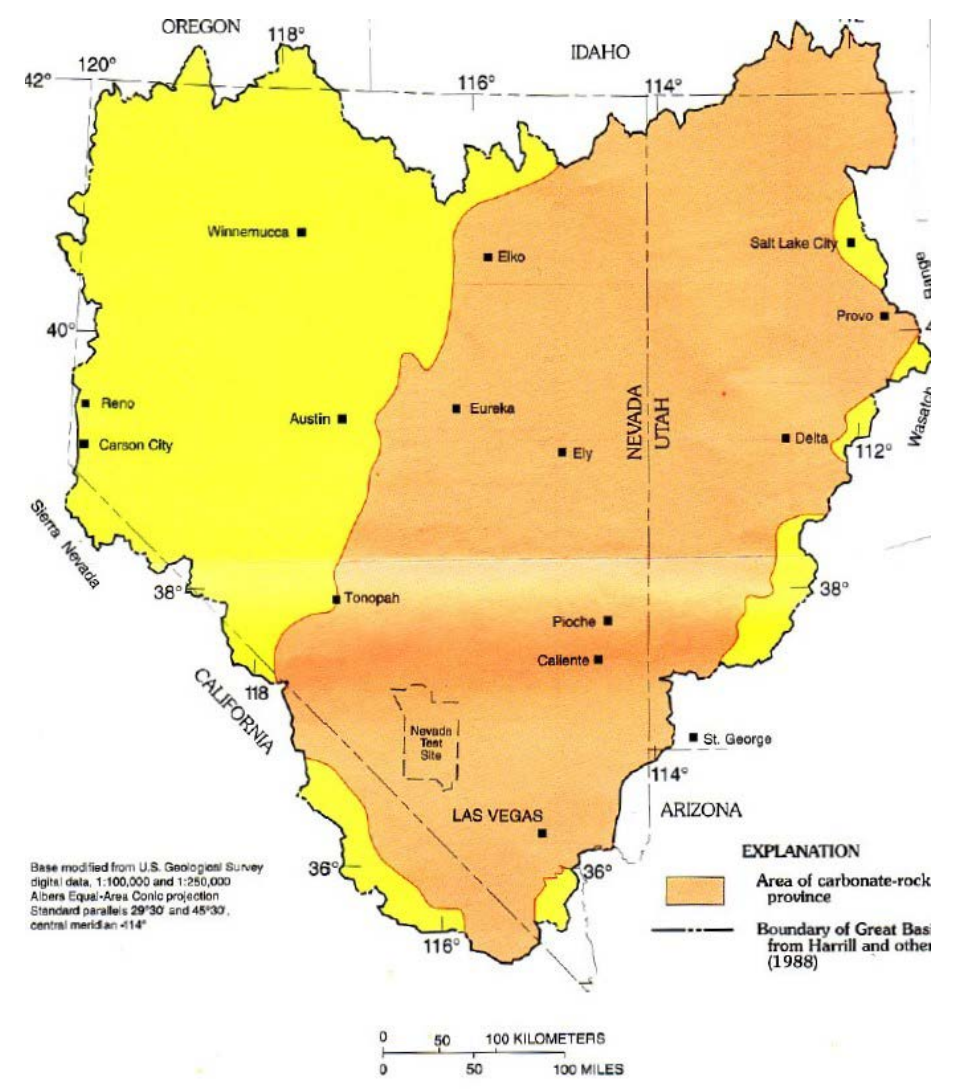

Figure 1. Location of carbonate rock province (LCAU) within GBCAAS. The 120-150-km-wide corridor of thickest carbonate occupies the western half of the carbonate province.

Source: Dettinger and Schaefner 1996

Multiple orogenies, extension episodes, and intrusive events have deformed and displaced the target formations of the LCAU (Dettinger et al. 1995). These structural disruptions have generated complexities of thickness, distribution, and permeability that can only be resolved with detailed geologic mapping, reconstruction, and modeling. The conceptual model of a deep permeable reservoir requires not only thick insulating sediments above, but also lateral protection from cold groundwater infiltration by either impermeable faults or impermeable bedrock. Without thermal insulation, cold groundwater infiltration has the potential to disperse both convective and conductive heat and result in heat flow loss (Sass et al. 1971). The oftentilted graben and half-graben nature of Nevada basins means that some permeable units may be deeply buried in part of a basin but much shallower or even exposed at the surface in another. Such a dipping or daylighting potential reservoir is less likely to be thermally insulated. This structural complexity and potential for dipping reservoirs further emphasizes the need for detailed geological, geophysical, and reservoir modeling. Thankfully, these lithologies and their contrasting physical properties are well-suited for geophysical techniques such as seismic 
reflection and magnetotellurics (e.g., unfractured and unsaturated carbonate rocks have very high resistivities: $>1,000 \mathrm{Ohm} \cdot \mathrm{m})$.

A pattern of carbonate-hosted petroleum reservoirs associated with felsic intrusives has been observed across the state of Nevada. These felsic intrusive bodies, ranging in age from early Cretaceous to $<3 \mathrm{Ma}$, are often related to ore deposition and extensive mineralization. Hulen (1991) and Hulen et al. (1990) point out that some of the carbonate reservoir rocks show evidence of hydrothermal alteration and hypothesized a high-temperature hydrothermal origin for fractured carbonate oil and gas reservoirs in the Blackburn Field (Pine Valley, Nevada) and Grant Canyon and Bacon Flat (Railroad Valley, Nevada). According to this model, hydrothermal fracturing related to emplacement of Tertiary intrusives created reservoir permeability in carbonate units in the Blackburn Field and hydrothermal convection is responsible for the thermal maturation of oil fields in Grant Canyon and Bacon Flat. In the latter case, hydrothermal circulation must have happened relatively recently $(<3 \mathrm{Ma})$. Both models require extensive, long-lived hydrothermal convection within sedimentary units to account for observed oil-field maturation and fracture patterns.

The relationship between present-day hydrothermal activity and older hydrothermal activity related to oil-field formation, the emplacement of felsic intrusive bodies, and ore deposition and mineralization is unclear. In the Blackburn Formation, several distinct phases of hydrothermal circulation, related to at least four episodes of fracturing, brecciation, and mineralization, were observed in Devonian dolomites. The oldest phase of fluid circulation was estimated at approximately $350^{\circ} \mathrm{C}-400^{\circ} \mathrm{C}$ based on mineral sequences and fluid inclusions. Later phases involve increasingly dilute aqueous solutions, with temperatures estimated between approximately $275^{\circ} \mathrm{C}-225^{\circ} \mathrm{C}$. The present-day reservoir rock is now hosting hydrothermal fluids at $\sim 120^{\circ} \mathrm{C}$ (Hulen et al. 1990).

Cross-cutting relationships of mineralized veins and fluid inclusion studies (Hulen 1991) show evidence for multiple episodes of thermal expansion-related fracturing and brecciating of dolomites. A primary episode is related to original pluton emplacement and fluids of approximately $350^{\circ} \mathrm{C}-400^{\circ} \mathrm{C}$. One or more secondary episodes of thermal expansion-related fracturing and brecciating of dolomites are related to post-emplacement hydrothermal fluid circulation, some of which featured distinct boiling episode(s). This boiling - presumably from a drop in reservoir pressure - could be the result of tectonic activity or the rupturing of a cap rock or reservoir "seal."

The key feature of the Hulen model is an upwelling geothermal plume, which heats the rocks at modern reservoir elevations to temperatures normally prevailing $3 \mathrm{~km}$ deeper (Figure 2). At the top of the plume, hot waters fortify the overlying basal valley-fill hydrocarbon seal by depositing silica and clay. The ascending hot waters enhance reservoir porosity by dissolving carbonate minerals. Using oil maturation temperatures relative to their expected depths may serve to inform understanding of deep thermal regimes and variability between basins. 


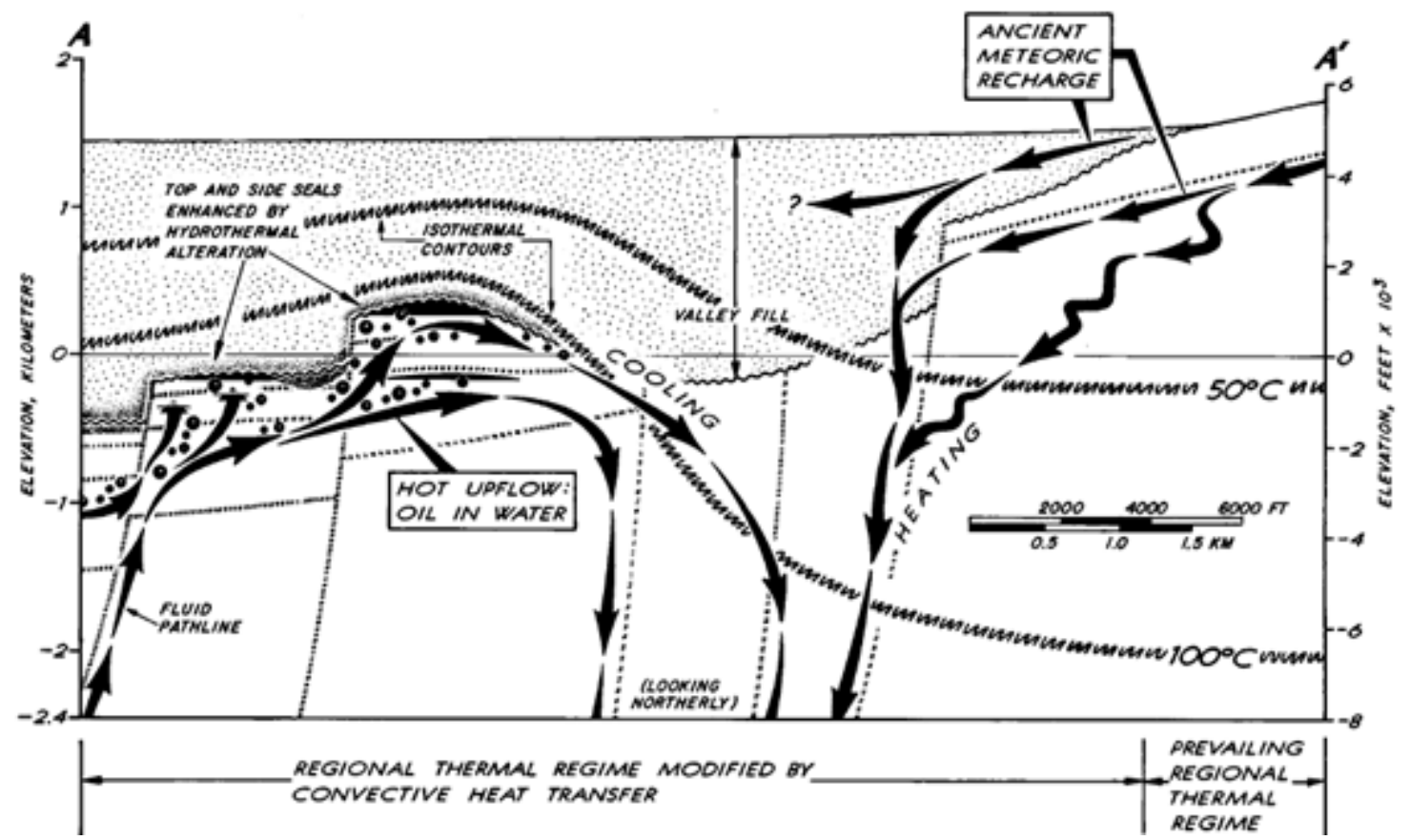

Figure 2. Conceptual model of geothermal evolution of the Grant Canyon and Bacon Flat oil reservoirs

Source: Hulen et al. 1994

\subsection{Data Mining}

The Elko Basin resides within the GBCAAS of eastern Nevada. The Elko Basin is of interest due to its large aerial extent and apparent relationship to Beowawe's hybrid geothermal resource (Simmons et al. 2017). The Elko Basin is divided into the following potential prospects:

Blackburn, Marys River, Tomera Ranch and Hay Ranch, North Willow Creek, and Diamond Valley. Steptoe Valley is also of interest due to its inclusion of the Monte Neva Hot Springs. Additionally, Bacon Flat in Railroad Valley is investigated because of the presence of hydrothermal alteration and one hot well. Additional data mining was conducted for Pavant Butte in the Black Rock Desert, Utah, because of its inclusion of volcanic features and a hot well drilled near the butte (Figure 3). 


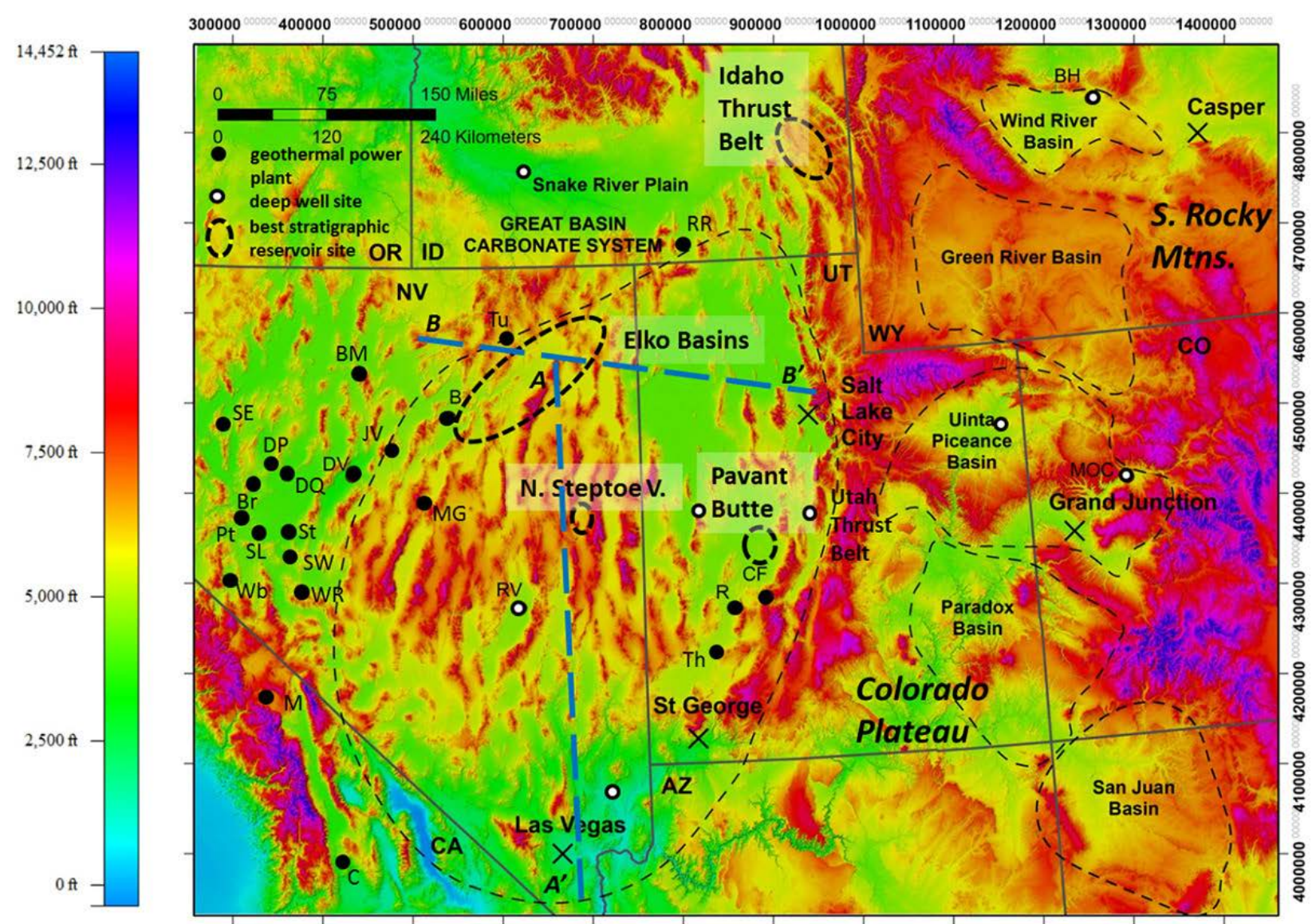

Figure 3. Shaded relief map (feet above sea level) of the eastern Great Basin and western Colorado Plateau. Power plant abbreviations are: B, Beowawe; BM, Blue Mountain; Br, Brady; C, Coso; CF, Cove Fort; DP, Desert Peak; DQ, Desert Queen; DV, Dixie Valley; M, Mammoth; MG,

McGinness; Pt, Patua; R, Roosevelt, RR, Raft River; SE, San Emidio; SL, Soda Lake; St, Stillwater; SW, Salt Wells; Th, Thermo; Tu, Tuscarora; W, Wabuska; and WR, Wild Rose. Deep-well abbreviations are: BH, Bighorn \#2-3 in Wind River Basin; MOC, Mobil O'Connell well in eastern Piceance Basin; and RV, Railroad Valley.

Source: Moore and Allis 2016

We then conducted searches of the Nevada state website, University of Nevada, Reno's website, Utah's state website, and the National Renewable Energy Laboratory's geothermal prospector to locate temperature, permeability, thickness, pressure, and formation top data. We also determined locations of existing wells. We then compiled the mined data into spreadsheets for analysis and created maps showing temperature gradients using a color scale, as well as plots of temperature versus depth linearly extrapolated to $4 \mathrm{~km}$ (Figure 4). We assumed a temperature of $21.5^{\circ} \mathrm{C}$ at $50 \mathrm{~m}$ depth for each plot. The plots of temperature versus depth are more telling, so the maps are not included in this report. 


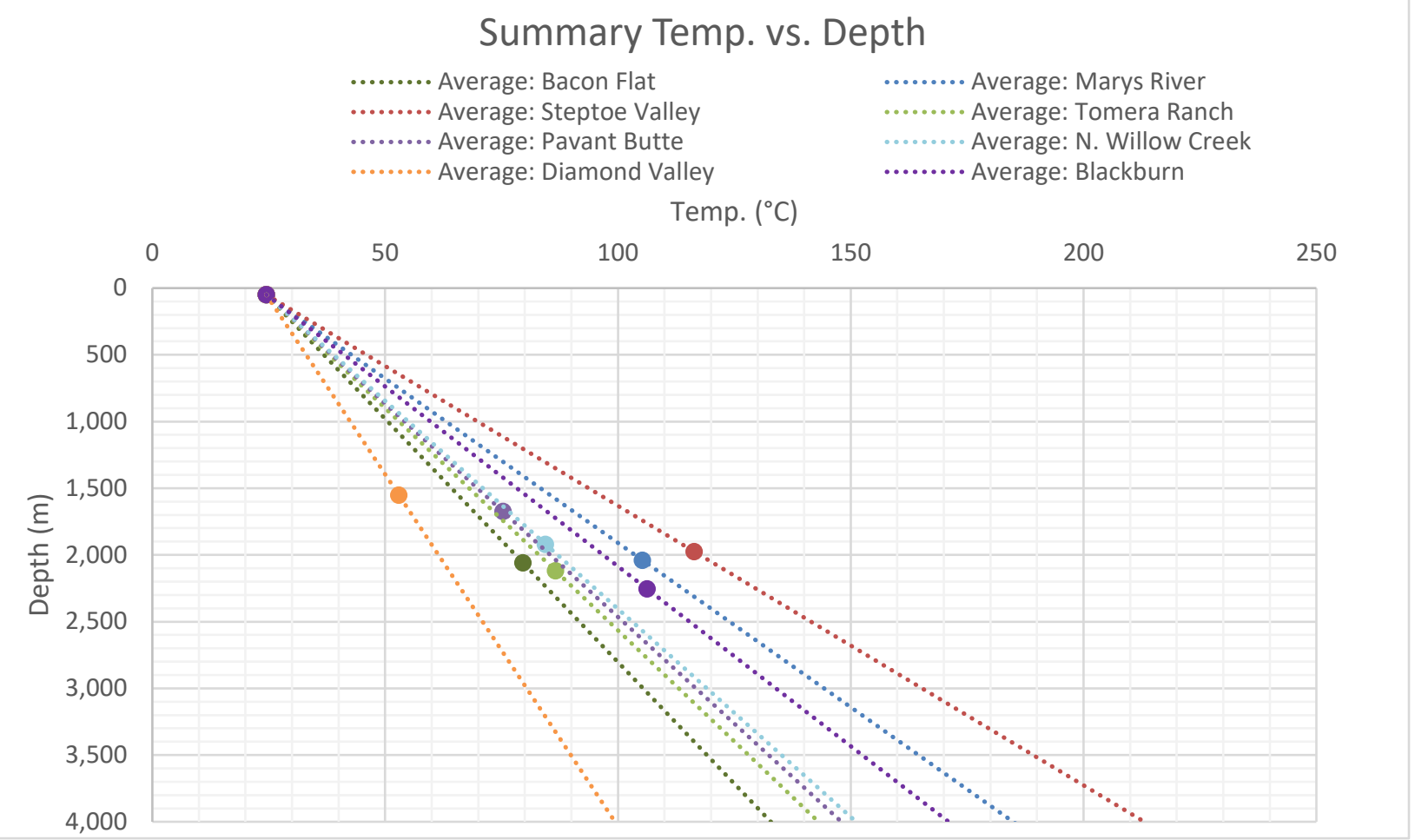

Figure 4. Plot of average bottom-hole temperature (BHT) versus depth linearly extrapolated to 4 km for wells in northeastern Nevada and western Utah. Data were pulled from oil and gas and geothermal well log databases. Fields analyzed include Bacon Flan in Railroad Valley, Nevada; Steptoe Valley, Nevada; Blackburn, Marys River, Tomera Ranch and Hay Ranch, North Willow Creek, and Diamond Valley, all in the Elko Basin, Nevada; and Pavant Butte, Utah. The dot represents the average depth of the wells in each field. These data were compiled using all wells with available BHTs at each field (between 1 and 16 wells per site, average of 8.4 wells per site). Temperature profiles in each field appear to be mostly linear.

Steptoe Valley, Marys River, and Blackburn appear to be the hottest basins of interest, measuring $150^{\circ} \mathrm{C}$ at about $2.7 \mathrm{~km}, 3.2 \mathrm{~km}$, and $3.5 \mathrm{~km}$, respectively. Note that these temperatures were measured before the wells were equilibrated and are uncorrected, meaning that they are likely underestimates. Figure 5 plots temperature versus depth for these three fields, including data from all wells where temperature data were found. Blackburn has the deepest average depth, as well as the most data points, meaning that it may produce a more accurate estimate of temperature at depth than Steptoe Valley and Marys River. However, Steptoe Valley's BHTs appear to be consistent except for two outliers, meaning that it may also serve as a good estimate of temperature at depth. 


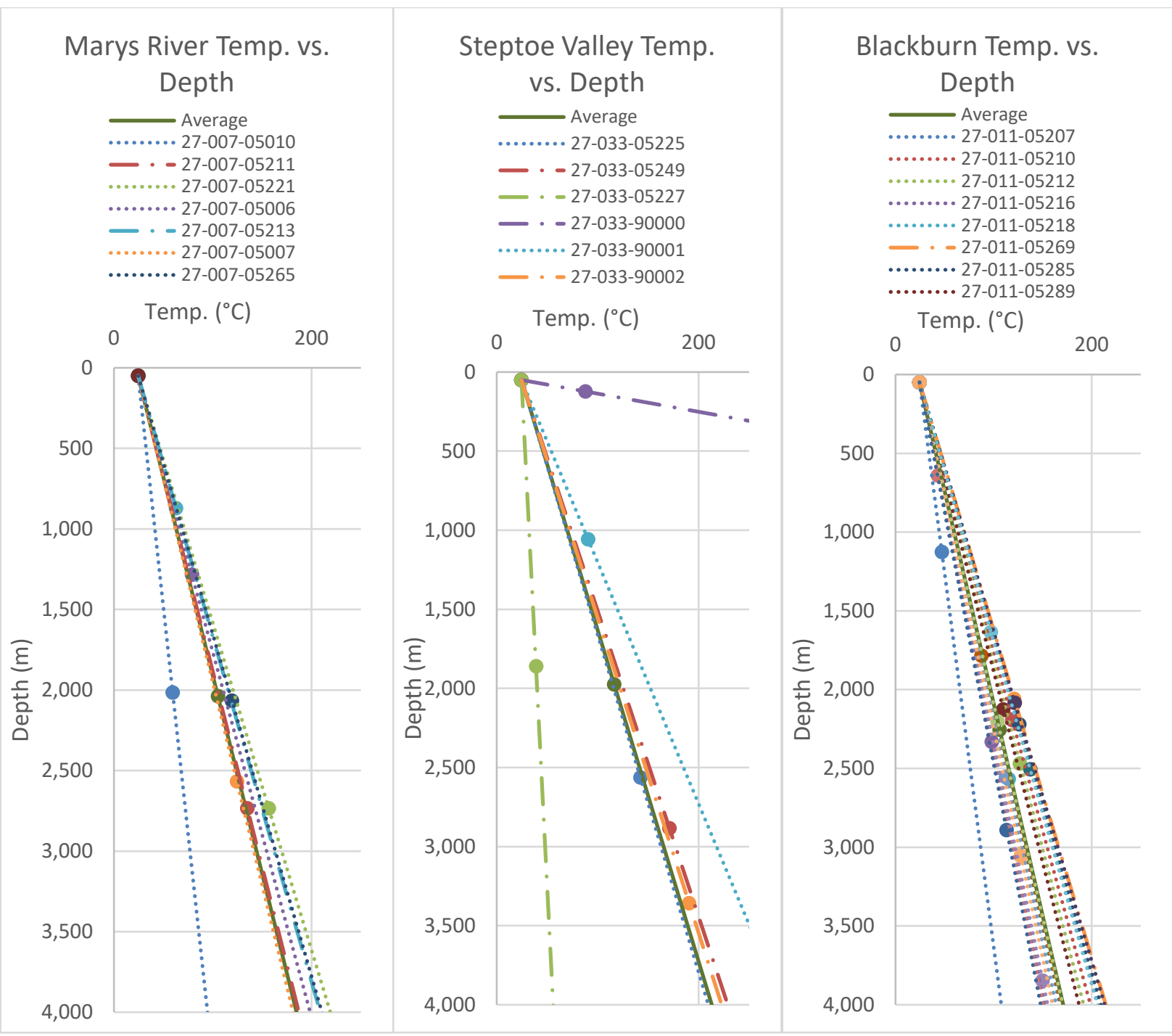

Figure 5. Plots of BHTs versus depth linearly extrapolated to $4 \mathrm{~km}$ for wells in basins with the highest temperatures: Marys River, Steptoe Valley, and Blackburn. The dots represent the depths of each temperature measurement, and the line types represent the type of temperature measurement (dotted: temperatures pulled from well log headers, dash-dotted: drill stem test temperature measurements, and solid: the average). Note that there is no apparent difference between BHTs measured by well logging equipment and BHTs measured during drill stem tests. Each API \# (e.g., 27-007-05211) represents a different well. The average gradient is the mean of all wells on each plot.

Pavant Butte and Bacon Flat have relatively low average BHTs. However, there are wells that, when linearly extrapolated, reach $200^{\circ} \mathrm{C}$ between $3.0 \mathrm{~km}$ and $3.2 \mathrm{~km}$ (Figure 6). This may point to the existence of one or more high-temperature features with small aerial extents, or it could be because these measurements extend into areas where little to no additional BHT data have been collected. Even so, these reservoirs could be economic with such high temperatures. 

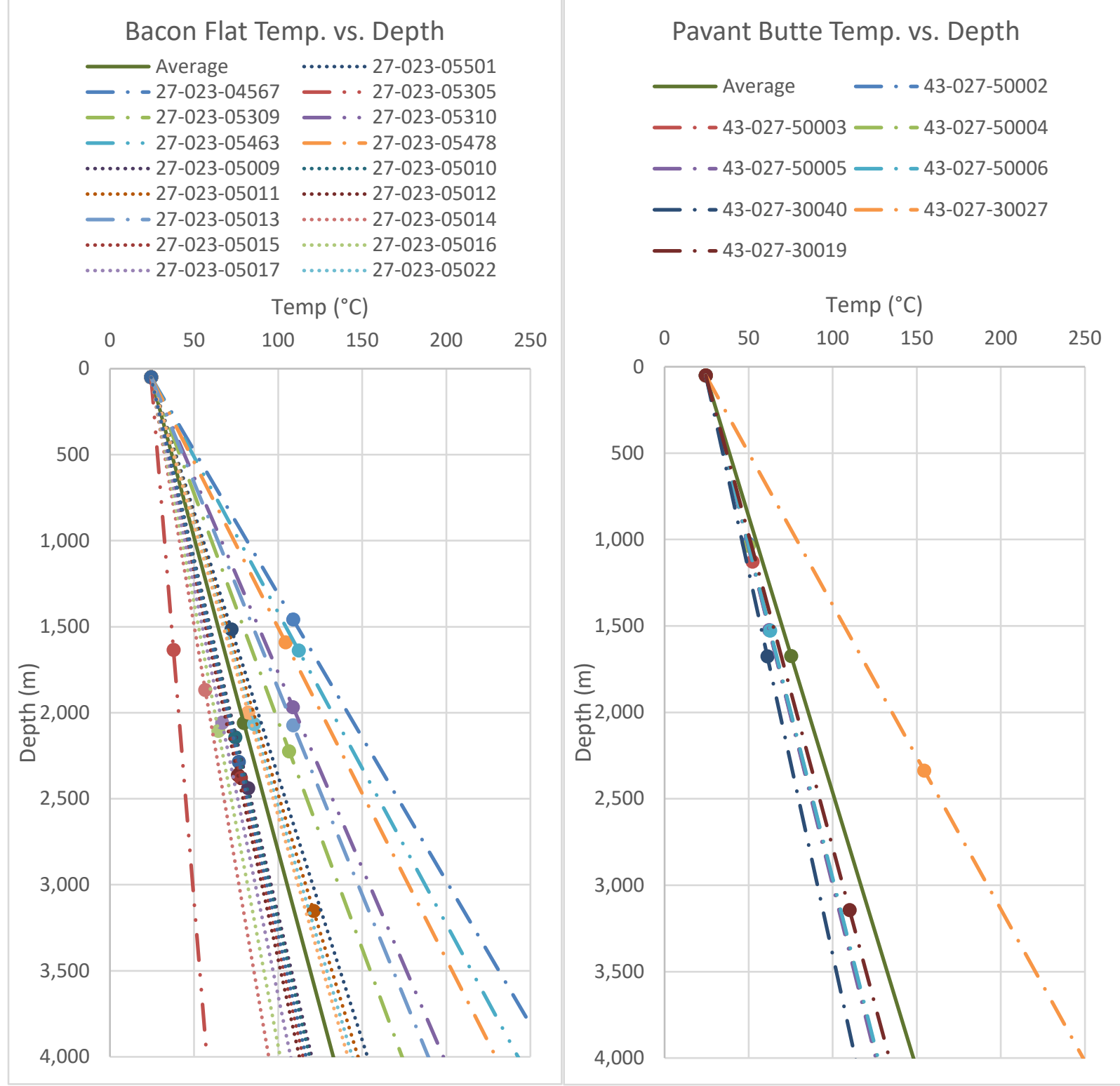

Figure 6. Plots of BHTs versus depth linearly extrapolated to $4 \mathrm{~km}$ for wells in the fields with isolated high-temperature anomalies: Bacon Flat and Pavant Butte. The dots represent the depths of each temperature measurement, and the line types represent the type of temperature measurement (dotted: temperatures pulled from well log headers, dash-dotted: drill stem test temperature measurements, dash-double-dotted: reservoir calculations, and solid: the average). Note that there is no apparent difference between BHTs measured by well logging equipment and BHTs measured during drill stem tests.

Following the BHT-based analysis, individual wells in Marys River, Steptoe Valley, Blackburn, Bacon Flat, and Pavant Butte were investigated in more detail to determine if any wells may be deepened. Table 1 shows a summary of wells that have not been plugged, with depths of at least $2 \mathrm{~km}$. 
Table 1. Wells That Have Not Been Plugged and May Be Evaluated for Deepening to Quantify Reservoir Properties

\begin{tabular}{|c|c|c|c|c|c|c|}
\hline Field & API & Well Name & $\begin{array}{l}\text { Completion } \\
\text { Date }\end{array}$ & $\begin{array}{l}\text { Total } \\
\text { depth } \\
\text { (m) }\end{array}$ & $\mathrm{BHT}\left({ }^{\circ} \mathrm{C}\right)$ & $\begin{array}{l}\text { Depth of } \\
\text { temperature } \\
\text { measurement }(\mathrm{m})\end{array}$ \\
\hline $\begin{array}{l}\text { Steptoe } \\
\text { Valley }\end{array}$ & $27-033-90002$ & Well No. $74-23$ & unknown & 3,358 & 191 & 3,358 \\
\hline $\begin{array}{l}\text { Steptoe } \\
\text { Valley }\end{array}$ & $27-033-05249$ & $\begin{array}{l}\text { Steptoe Federal } \\
\text { No. } 17-14\end{array}$ & $31-$ Oct-84 & 3,566 & 170 & 2,884 \\
\hline Marys River & $27-007-05211$ & $\begin{array}{l}\text { Marys River } \\
\text { Federal No. } 1\end{array}$ & 8-May-78 & 3,696 & 135 & 2,733 \\
\hline Blackburn & 27-011-05304 & $\begin{array}{l}\text { Lucky Seven } \\
\text { Federal No. } 1\end{array}$ & 2-Feb-03 & 3,152 & 113 & 2,555 \\
\hline Blackburn & 27-011-05202 & Nost I No. 1 & 26-Mar-77 & 3,202 & 133 & 2,891 \\
\hline $\begin{array}{l}\text { Pavant } \\
\text { Butte }\end{array}$ & $43-027-30027$ & Pavant Butte 1 & unknown & 3,810 & 154 & 2,338 \\
\hline Bacon Flat & $27-023-05527$ & Federal No. 11-14 & 25-Feb-95 & 3,353 & unknown & unknown \\
\hline
\end{tabular}

Attractive basins within the GBCAAS typically contain $2-3 \mathrm{~km}$ of basin-fill sediments. A basin depth map derived from gravity models suggests that some basins may be deeper than 3-4 km (Gwynn et al. 2014). An ideal deepening candidate is a deep, large-diameter well with a high geothermal gradient, a thick section of deep carbonates (basin depth $>4 \mathrm{~km}$ ), and good integrity. More work needs to be done to downselect attractive deepening candidates, such as estimating the necessary additional footage to reach target carbonates of the LCAU and integrity testing of the prospective wells. Integration of logged formation tops, along with the purchase and analysis of privately held legacy seismic data, would help this effort.

\subsection{Area Selected for Reservoir and Techno-Economic Modeling}

One attractive area with significant basin depth resides between two hot wells in Marys River Basin-North (Figure 7). Marys River Federal 1-8 is northeast of this area, and this well has a measured temperature of $157^{\circ} \mathrm{C}$ at a total depth of $2,734 \mathrm{~m}$. Wilkins Ranch 1 is southeast of this area, and this well has a measured temperature of $124^{\circ} \mathrm{C}$ at a total depth of $2,567 \mathrm{~m}$. Drilling a new well in this attractive area may find reservoirs with temperatures approaching $180^{\circ} \mathrm{C}$ at 3.5 $\mathrm{km}$. Well data suggest that a new well in the selected area will encounter Paleozoic carbonates at depths below $2.5 \mathrm{~km}$. Marys River Federal 1-8 was within Paleozoic sediments at 2,655 m (Ordovician carbonates), and Wilkins Ranch 1 was within Paleozoic sediments at 2,448 m (Mississippian shales). 


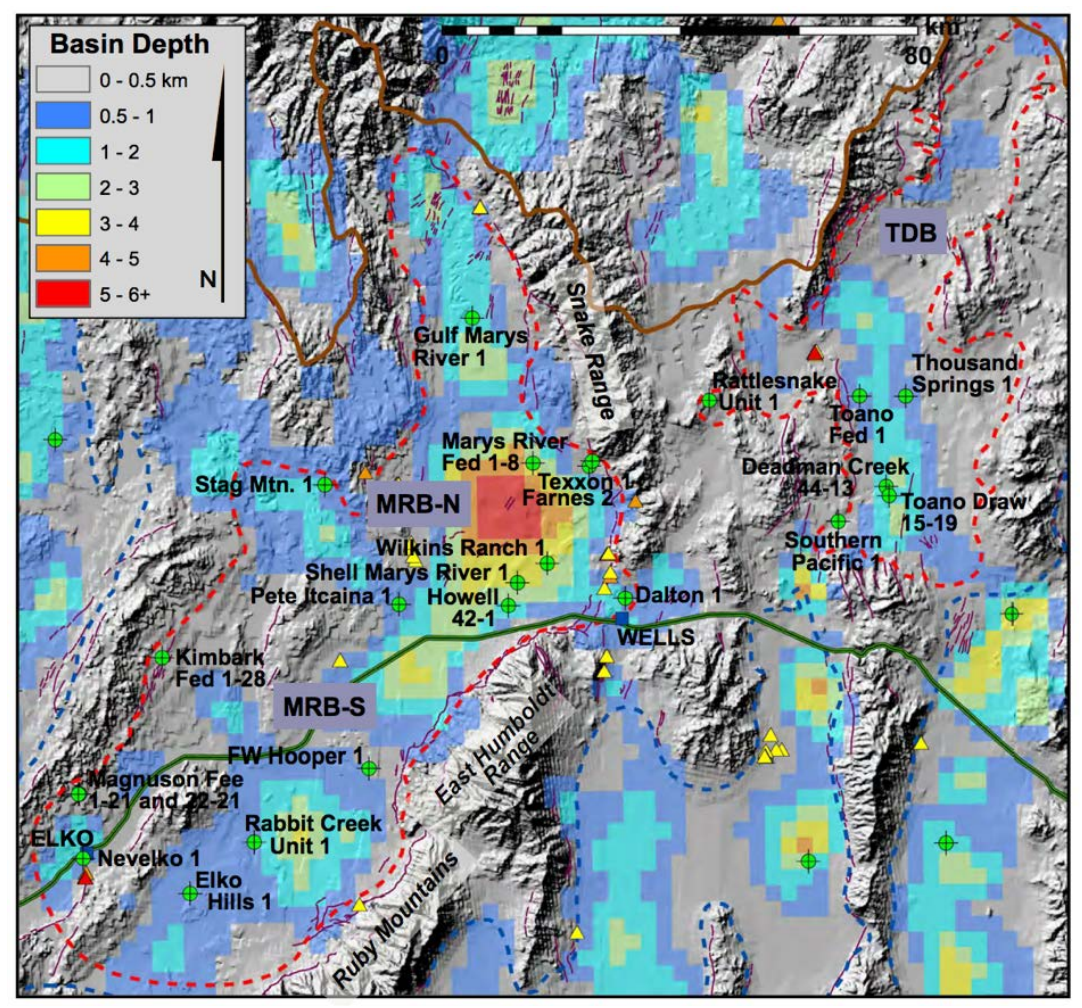

Figure 7. Oil wells drilled in Marys River Basin

Source: Gwynn et al. 2014

The selected area is approximately $100 \mathrm{~km}^{2}$ in areal extent (Figure 7). Reservoir properties are based on values used by others to model target reservoirs within consolidated Paleozoic bedrock in this region of eastern Nevada (Deo et al. 2014). Differences between the published reservoir model and the reservoir model used in this study are listed in Table 2.

Table 2. Differences Between a Published Reservoir Model and the Model Used in This Study

\begin{tabular}{cccc}
\hline Reservoir property & Published reservoir model & Reservoir model used in this study & Units \\
\hline Mid-Reservoir Depth & 3 & 3.5 & $\mathrm{~km}$ \\
$\quad$ Mid-Reservoir & 200 & 180 & ${ }^{\circ} \mathrm{C}$ \\
$\quad \begin{array}{l}\text { Temperature } \\
\text { Mid-Reservoir } \\
\quad \text { Pressure }\end{array}$ & 30 & 35 & $\mathrm{MPa}$ \\
$\begin{array}{c}\text { Maximum Injection } \\
\text { Pressure at Mid- } \\
\text { Reservoir Depth }\end{array}$ & 32.4 & 37.4 & $\mathrm{MPa}$ \\
\hline
\end{tabular}

CMG STARS (2019) was used for reservoir modeling. The sandwich model described by Deo et al. (2014) and used in this study has four target reservoirs within a 1-km-thick section of consolidated bedrock. Each of the four reservoirs is $25 \mathrm{~m}$ thick and has $100 \mathrm{mD}$ permeability (Figure 8). The simulated temperature profile (Figure 9) was evaluated in a techno-economic analysis using Geophires (Beckers and McCabe 2019). Well spacing and other techno-economic input parameters are listed in Table 3. 


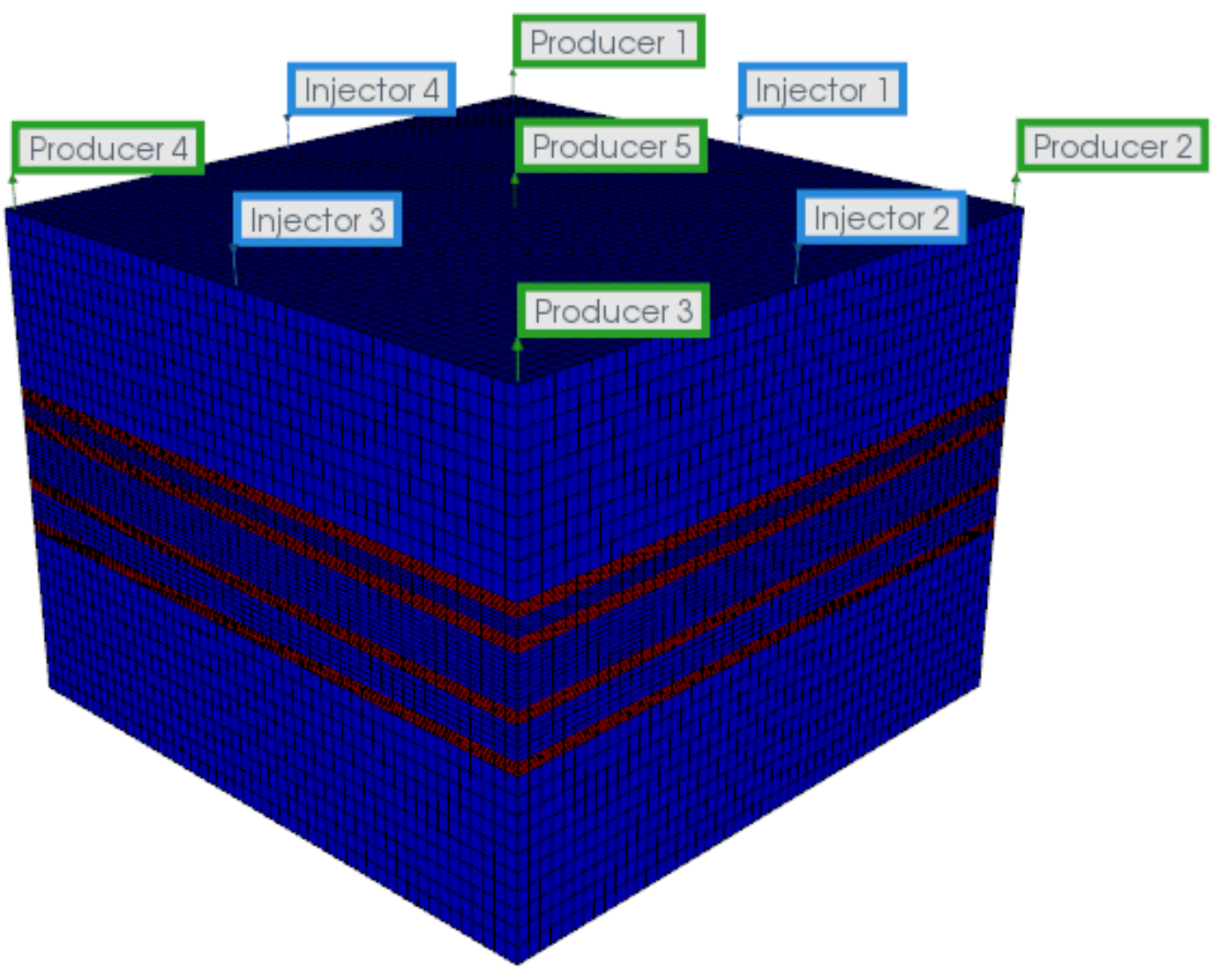

Figure 8. Reservoir layers and well locations in CMG STARS model

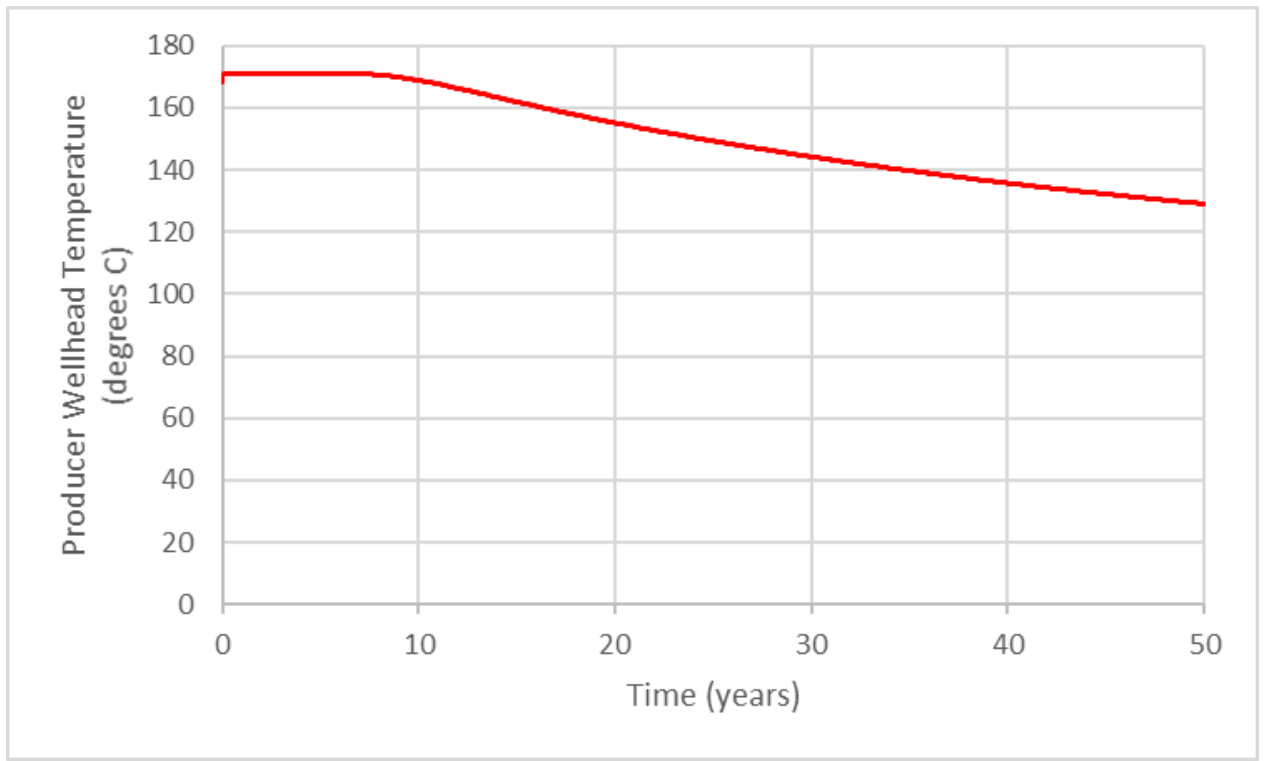

Figure 9. Producer wellhead temperature profile when mass flow rate $=63 \mathrm{~kg} / \mathrm{s}$ per well 
Table 3. Techno-Economic Input

\begin{tabular}{ll}
\hline \multicolumn{1}{c}{ Parameters } & \multicolumn{1}{c}{ Values } \\
\hline Rock Segment 1 Top Depth and Temperature & $0 \mathrm{~m}, 15^{\circ} \mathrm{C}$ (default in Geophires) \\
Rock Segment 1 Bottom Depth and Temperature & $50 \mathrm{~m}, 21.5^{\circ} \mathrm{C}$ \\
Rock Segment 1 Geothermal Gradient & $130^{\circ} \mathrm{C} / \mathrm{km}$ \\
Rock Segment 2 Top Depth and Temperature & $50 \mathrm{~m}, 21.5^{\circ} \mathrm{C}$ \\
Rock Segment 2 Bottom Depth and Temperature & $3 \mathrm{~km}, 162.5^{\circ} \mathrm{C}$ \\
Rock Segment 2 Geothermal Gradient & $48^{\circ} \mathrm{C} / \mathrm{km}$ \\
Rock Segment 3 Top Depth and Temperature & $3 \mathrm{~km}, 162.5^{\circ} \mathrm{C}$ \\
Rock Segment 3 Bottom Depth and Temperature & $4 \mathrm{~km}, 197.5^{\circ} \mathrm{C}$ \\
Rock Segment 3 Geothermal Gradient & $35^{\circ} \mathrm{C} / \mathrm{km}($ Deo et al. 2014) \\
Number of Injection Wells per km ${ }^{2}$ & $2(\mathrm{Deo} \mathrm{et} \mathrm{al.} \mathrm{2014)}$ \\
Number of Production Wells per km ${ }^{2}$ & $2(\mathrm{Deo}$ et al. 2014) \\
Injection and Production Well Tubing Diameter & outer diameter $=5.5 \mathrm{inches}$ \\
& inner diameter $=4.778$ inches \\
Well Productivity and Injectivity Index & $2.25(\mathrm{~kg} / \mathrm{sec}) / \mathrm{bar}$ \\
Injection Bottom-Hole Pressure and Temperature & $37.4 \mathrm{MPa}, 100^{\circ} \mathrm{C}$ \\
Production Wellhead Pressure with Pump at 1,500 m & $842 \mathrm{kPa}$ \\
Rock Density, Heat Capacity, Thermal Cond. & $2,700 \mathrm{~kg} / \mathrm{m}^{3}, 869 \mathrm{~J} /(\mathrm{kg} \cdot \mathrm{K}), 2.5 \mathrm{~W} /(\mathrm{m} \cdot \mathrm{K})$ \\
Power Plant Type & Subcritical Organic Rankine Cycle \\
Economic Model & $\mathrm{BICYCLE} \mathrm{levelized} \mathrm{cost} \mathrm{model}$ \\
Weighted Average Cost of Capital & $8.75 \%$ \\
\hline
\end{tabular}

Three areal extents were evaluated (Table 4). Techno-economic results are similar to published values for a 30-year field life with well rates ranging from 31 to $127 \mathrm{~kg} / \mathrm{sec}$ (Allis et al. 2013). Critical uncertainties not evaluated include reservoir thickness, permeability, porosity, and lateral continuity. Exploration wells in the selected area would help quantify these parameters and reduce other subsurface uncertainties. These LCOEs are higher than traditional hydrothermal systems due to increased well depths.

Table 4. Techno-Economic Results for Mass Flow Rate $=63 \mathrm{~kg} / \mathrm{s}$ Per Well and 50-Year Field Life

\begin{tabular}{ccccc}
\hline $\begin{array}{c}\text { Developed } \\
\text { Area }\left(\mathbf{k m}^{\mathbf{2}}\right)\end{array}$ & $\begin{array}{c}\text { No. of Wells } \\
\text { (Inj + Prd) }\end{array}$ & $\begin{array}{c}\text { Total Capital } \\
\text { Cost (\$M) }\end{array}$ & $\begin{array}{c}\text { Average Net Electricity } \\
\text { Generation (MWe) }\end{array}$ & $\begin{array}{c}\text { LCOE } \\
\text { (cents/kWhr) }\end{array}$ \\
\hline 1 & 4 & 67 & 5 & 18 \\
5 & 20 & 297 & 24 & 15 \\
10 & 40 & 578 & 48 & 14 \\
\hline
\end{tabular}




\section{Colorado}

Colorado has seven major sedimentary basins, all thought to have high heat flow relative to the continental average. Several of these basins are foreland basins. Foreland basins tend to have significant crustal subsidence towards the orogen, resulting in lithospheric bending that forms areas of local extension and normal faulting. This may cause local positive geothermal gradients, especially when faults or highly permeable layers allow advective heat transport from the deeper to the shallower parts of a foreland basin (Moeck 2014). Geologic descriptions of three sedimentary basins - Denver, Piceance, and Raton - are presented in this section.

Heat flow within the three Colorado sedimentary basins reviewed as part of this study was calculated in targeted studies by the Colorado Geologic Survey and Colorado School of Mines. These calculations are based on data sets with significant limitations (shallow wells, uncorrected BHTs, etc.) and are somewhat variable, but produce values consistently higher than the global continental average of $65 \mathrm{~mW} / \mathrm{m}^{2}$ for all three basins. Heat flow in the Raton Basin is the highest, averaging $122.9 \mathrm{~mW} / \mathrm{m}^{2}$ - almost double the global average. However, permeability measurements from specific sedimentary formations with high heat flow have not been obtained.

\subsection{Denver Basin}

Allis et al. (2013) ranked the Denver Basin as "mid-range and needing further evaluation" in their analysis of U.S. sedimentary basins for geothermal energy. The Denver Basin, also known as the Denver-Julesburg Basin, is a structural basin consisting of a large asymmetric syncline and a surface area of $\sim 155,000 \mathrm{~km}^{2}$ (Curtis 1988). The stratigraphic sequence of the Denver Basin is dominated by subaerial deposits, with minimal carbonates (Abbott and Noe 2002). There is an abundance of well data for the Denver Basin. Porro and Augustine (2012) estimated the geothermal energy resource in the Denver Basin based on corrected BHTs. Their results indicate temperatures of $100^{\circ} \mathrm{C}-150^{\circ} \mathrm{C}$ at $2.5-4-\mathrm{km}$ depth for parts of the basin, with thermal energy in place approximately $1 \times 10^{19} \mathrm{~kJ}$ (this includes thermal energy in both rock and pore fluids). However, they found that the basin has moderate to low flow rates and generally low permeability. Crowell, Oschsner, and Gosnold (2012) claim that Denver Basin temperatures may be higher than Porro et al. (2012) assumed: $160^{\circ} \mathrm{C}$ at $3-\mathrm{km}$ depth and $210^{\circ} \mathrm{C}$ at $4-\mathrm{km}$ depth, with average heat flow of $90 \mathrm{~mW} / \mathrm{m}^{2}$, based on a temperature correction factor specific to the Denver Basin that they developed. Another study by the same authors from one year later conducts a volumetric analysis using BHTs from thousands of wells in the Upper Cretaceous (mostly limestone and dolomite formations) of the Denver Basin (Crowell and Gosnold 2013). This study gives a range of recoverable heat estimations from these units between $2.6 \times 10^{14}$ and $7.3 \times 10^{17}$ $\mathrm{J}$ (i.e., $7.3 \times 10^{4}$ and $2.0 \times 10^{8} \mathrm{MWt}$ ), implying the reservoir temperature should approach $200^{\circ} \mathrm{C}$ at $2-3 \mathrm{~km}$ of unconsolidated sediments.

A geothermal anomaly within the Wattenberg Field in the Denver Basin was first identified from isoreflectance contour maps (Higley, 1988). The Wattenberg Field is a large oil and gas accumulation from which several Cretaceous-age sedimentary reservoirs produce hydrocarbons. The geothermal anomaly is located where the Colorado Mineral Belt intersects the Denver Basin. The Colorado Mineral Belt is a northeast-trending, $\sim 500-\mathrm{km}$-long, 25-50-km-wide belt of Late Cretaceous-Paleogene-aged plutons and associated ore deposits across the state of Colorado (Chapin 2012). 
Two sandstone-bearing intervals within the "Sussex" and "Dakota" groups of Cretaceous age within Wattenberg Field show a moderately high geothermal gradient of $43^{\circ} \mathrm{C} / \mathrm{km}$ and reservoir temperatures of $100^{\circ} \mathrm{C}-120^{\circ} \mathrm{C}$ at $2.1-2.5 \mathrm{~km}$, based on corrected BHTs (Morgan et al., 2009). However, permeability appears to be a concern in these formations and across the basin. Very small volumes of water are produced from productive oil and gas zones in the Denver-Julesburg Basin (Rob Swartwout, Horizon Resources, pers. comm.). On the other hand, most oil and gas production come from horizontal wells in formations of Cretaceous age or younger, leaving the possibility that units with higher permeabilities exist stratigraphically below the units penetrated by oil and gas wells. Augustine and Zerpa (2016) conducted a reservoir characterization of the Lyons Sandstone Formation of the Wattenberg Field, which is a Permian sandstone formation used for water disposal. The top of the Lyons Formation was determined to be located at a depth of approximately $2.8-3 \mathrm{~km}$, with a thickness ranging from approximately $20-50 \mathrm{~m}$. The calculated geothermal gradient in that study ranged from $25.5^{\circ} \mathrm{C} / \mathrm{km}$ to $46.8^{\circ} \mathrm{C} / \mathrm{km}$ with an average of $37.2^{\circ} \mathrm{C} / \mathrm{km}$, yielding a calculated temperature at the formation top of $105.6^{\circ} \mathrm{C}-145.5^{\circ} \mathrm{C}$. That study also estimated the porosity of the formation from geostatistical averages from well log data. They developed a correlation between porosity and permeability using three core data sets with permeability measurements from the Lyons Formation. The production performance of this formation was evaluated under three permeability scenarios (low, medium, and high) and five design cases: a vertical well without fractures, a vertical well with fractures, a horizontal well with open-hole completion, a horizontal well with longitudinal fractures, and a horizontal well with multistage transverse fractures. That study concluded that for the low-permeability scenarios (2.81 mD to $25.2 \mathrm{mD})$, "advanced enhancement techniques" would need to be employed; for the intermediate-permeability scenarios $(7.81 \mathrm{mD}$ to $78 \mathrm{mD})$, horizontal wells and hydraulic fracturing would facilitate the thermal recovery in a geothermal reservoir. However, for the higher-permeability scenarios $(30.3 \mathrm{mD}$ to $299 \mathrm{mD})$, the application of hydraulic fracturing did not improve the system performance significantly.

\subsection{Piceance Basin}

The Piceance Basin in western Colorado is thought to be hotter than the Denver Basin and perhaps more permeable (Rob Swartwout, Horizon Resources, pers. comm). It is a Laramide-age structural basin, from which commercial quantities of oil and gas have been produced. The Piceance stratigraphic sequence is dominated by subaerial deposits with one notable carbonate formation, the Mississippian Limestone, where major permeability results from karst structures locally increased by fracturing (Morgan 2015). Morgan (2015) calculated corrected thermal gradients from over 27,000 BHTs. These calculations consistently indicate two distinct thermal gradients across the basin: a lower gradient $<2,000 \mathrm{~m}$ and a higher gradient beyond this depth. The lower gradient is associated with siliciclastic formations, which have a higher thermal conductivity relative to other formations within the basin. The higher gradient, found below 2,000-m depth, is associated with coal-bearing formations and shales. Comparison of gradients from across the basin shows that temperatures ranging from $125^{\circ} \mathrm{C}$ to $170^{\circ} \mathrm{C}$ can consistently be found at depths $<4 \mathrm{~km}$.

The most suitable formation for geothermal reservoirs is the Mississippian Leadville Limestone, a highly fractured unit that occurs between two confining layers within a package of Paleozoic carbonate units up to 800-m thick in Colorado. This unit is geologically contiguous with largescale Mississippian carbonate deposits in the western United States such as the Madison 
Formation, which extends from Canada to Arizona. Thermal waters, including the hot springs at Glenwood Springs, Colorado, issue from the Leadville Limestone Formation when it is exposed at the surface. However, measured hydraulic conductivity and transmissivity of this unit is highly variable, and it is a function of the extent to which the unit has undergone faulting and fracturing (Geldon 1989).

Geldon (1989) investigated the Leadville Limestone as part of a U.S. Geological Survey-led regional aquifer system analysis of the Colorado River Basin, calculating hydraulic conductivity values for the Devonian and Mississippian carbonate units. Twelve hot springs and six seepage areas in Glenwood Springs were the subject of aquifer tests of the Leadville Limestone between 1981 and 1985. Those tests found a cumulative discharge rate between 15 and $19 \mathrm{~m}^{3} / \mathrm{min}$ for the unit, which is thought to be $60-\mathrm{m}$ thick in the area and consist of both limestone and dolomite. Wells drilled in the area intersected the top of the Leadville Limestone Formation at $274 \mathrm{~m}$. The deepest well terminated at $305 \mathrm{~m}$, in rocks described as "limestone and dolomite." Well test data (from drill stem tests, one pumping test, and two flow tests) from the Piceance Basin and from the Glenwood Springs area were analyzed to interpret the transmissivity, storage coefficient, and hydraulic conductivity of the Leadville Limestone (including the Dyer Dolomite subunit) (Geldon 1989). That study found that the hydraulic conductivity ranged from 0.00017 to 0.0030 $\mathrm{m} / \mathrm{d}$ in the Piceance Basin to at least $52 \mathrm{~m} / \mathrm{d}$ in the intensely faulted uplifted area near Glenwood Springs. These results indicate that hydraulic conductivity values in the center of uplifted areas are at least three orders of magnitude larger than in the center of the Piceance Basin. Transmissivity values of the Leadville Limestone, obtained from aquifer tests at Glenwood Springs and calculated from the product of unit thickness and hydraulic conductivity in other areas, range from less than 0.009 to $0.9 \mathrm{~m}^{2} / \mathrm{d}$ in structural basins and from 0.9 to more than 93

$\mathrm{m}^{2} / \mathrm{d}$ in uplifted areas. The transmissivity in the vicinity of Glenwood Springs was calculated at $4,366 \mathrm{~m}^{2} / \mathrm{d}$.

\subsection{Raton Basin}

The Raton Basin is smaller than the Piceance and the Denver Basins, with an areal extent of about $5,700 \mathrm{~km}^{2}$, and extends into northern New Mexico. It is one of many small basins associated with extensional activity along the Rio Grande Rift. The Rio Grande Rift spans approximately $1,000 \mathrm{~km}$ from Leadville, Colorado, into northern New Mexico and is an extensional feature containing a series of asymmetrical half grabens (McDonald et al. 2011). Within the basins, Paleozoic carbonates are overlain by Mesozoic clastic deposits, sometimes overlain by Tertiary volcanic deposits associated with the onset of rifting. This sequence is typically capped with sediments associated with subsequent basin subsidence. The region has been evaluated for potential geothermal applications due to high heat flow and presence of hot springs. Geothermal investigations have been of both regional scale as well as prospect scale, such as Mt. Princeton, San Luis Basin, and Raton Basin in Colorado and several sites in New Mexico, including one that has been developed for power generation (Lightning Dock, New Mexico) and one that was the focus of a U.S. Department of Energy (DOE)-funded Play Fairway Analysis exploration project (White Sands Missile Range, New Mexico). Morgan (2009) and Bohlen (2012) both found that heat flow in the Raton Basin is almost double the global continental average of $65 \mathrm{~mW} / \mathrm{m}^{2}$. The source of this anomalously high heat flow remains a mystery (Bohlen 2012) but is likely due to a combination of deep circulation along normal faults 
and localized crustal thinning due to rifting. In general, heat flow is higher in the eastern part of the basin.

Bohlen (2012) identified the Pennsylvanian/Permian Sangre de Cristo Formation as a target formation for geothermal exploration in the Raton Basin. This formation has not been extensively drilled. Most wells in the Raton Basin terminate at $<1-\mathrm{km}$ depth, which is too shallow to encounter this unit. The Sangre de Cristo Formation is a complex suite of sediments, including some carbonates, and outcrops at the west end of the basin. Permeability in the Sangre de Cristo units is unknown but thought to be high due to lost circulation in the few deeper wells that penetrate the formation (Bohlen 2012). The Madera Formation is a limestone unit with thicknesses of up to $1,210 \mathrm{~m}$ (McDonald et al. 2011). There are hot springs and wells located to the west of Trinidad, Colorado, and heat flow in this area approaches $200 \mathrm{~mW} / \mathrm{m}^{2}$ (McDonald et al. 2011).

Morgan (2009) and Bohlen (2012) calculated the thermal gradient in the Raton Basin from $>1,000$ predominantly shallow wells and found ranges from $40^{\circ} \mathrm{C} / \mathrm{km}$ to $60^{\circ} \mathrm{C} / \mathrm{km}$, with an average of $49.2^{\circ} \mathrm{C} / \mathrm{km}$. Bohlen (2012) extrapolated temperatures at three depth intervals based on thermal gradient calculations and found that temperatures of $175^{\circ} \mathrm{C}$ and higher could be encountered at 3-km depth. Heat flow within the basin, calculated using a generic thermal conductivity value due to lack of measurements, is highly variable but averages $122.9 \mathrm{~mW} / \mathrm{m}^{2}-$ almost double the global continental average of $65 \mathrm{~mW} / \mathrm{m}^{2}$. Using a simplified volumetric heatin-place model, Bohlen (2012) estimated that the power capacity of a geothermal reservoir in the Raton Basin could be conservatively estimated at 70 MWe. McDonald et al. (2011) evaluated the Raton Basin for geothermal applications as part of their large-scale geothermal evaluation of the Rio Grande Rift in Colorado and New Mexico. They report heat-flow values of $>200 \mathrm{~mW} / \mathrm{m}^{2}$ and thermal gradients of $60^{\circ} \mathrm{C} / \mathrm{km}$. They also predict a depth to the $90^{\circ} \mathrm{C}$ isotherm at $1.3 \mathrm{~km}$ and a depth to the $150^{\circ} \mathrm{C}$ isotherm at $2.8 \mathrm{~km}$.

The Raton Basin is a fault-bounded structural basin, an asymmetric syncline dominated by subaerial sedimentary formations with localized basalt flows and igneous intrusions (Watts 2006). Volcanism in the basin began in the Tertiary and continues into the present, in conjunction with the uplift and block faulting that is responsible for the present-day Rio Grande Rift Valley (Bohlen 2012). Coal-bed methane is produced from sedimentary reservoirs within the Raton Basin, with coal-, gas-, and oil-bearing formations at relatively shallow depths (Cenozoic and Mesozoic Vermejo, Niobrara, and Graneros Formations). Normal faulting within the basin displaces strata $\sim 15 \mathrm{~m}$. The thickness of unconsolidated sedimentary strata ranges from 3.0-7.6 km (Topper, Scott, and Watterson 2011), but the deep subsurface geology of the Raton Basin is not well known due to the scarcity of deep wells (Bohlen 2012).

\subsection{Data Mining}

A relatively brief data-mining effort was applied to the basins of Colorado. No new permeability data were located; however, BHTs were found for the Canon City Embayment, Hugoton Embayment, and North Park, Paradox, Piceance, Raton, and Sand Wash Basins (Dixon 2004). BHTs in the Canon City Embayment and Raton Basin yield anomalously high temperature gradients (Figure 10), up to $>70^{\circ} \mathrm{C} / \mathrm{km}$ in the eastern part of the Raton Basin. Calculated geothermal gradients of the Hugoton Embayment, North Park, Paradox, Piceance, and Sand Wash Basins tend to be slightly above average at $\sim 40^{\circ} \mathrm{C} / \mathrm{km}$, with certain wells in the Piceance 
and North Park Basins reaching values of $\sim 50^{\circ} \mathrm{C} / \mathrm{km}-60^{\circ} \mathrm{C} / \mathrm{km}$ (Figure 10). Additional data were not obtained for the Denver Basin due to the abundance of previous studies.

Targets for geothermal production in Colorado sedimentary basins include high-porosity/highpermeability formations, fault/fracture zones, and karst zones in carbonate rock. These types of units have been identified in all three of Colorado's sedimentary basins: (1) the Wattenberg Field in the Denver Basin, (2) the Leadville Limestone in the Piceance Basin, and (3) the Sangre de Cristo Formation in the Raton Basin. Data such as lost circulation events, resistivity logs, and injectivity measurements can give indirect permeability measurements; however, this is limited by the fact that very few wells penetrate these deeper formations. A map of injection wells in the Raton Basin is given in Figure 11; however, the injector formations (i.e., Dakota-Purgatoire, Dakota, Entrada, Niobrara, and Morrison) are not formations of interest in this study, which targets deeper formations with higher temperatures.

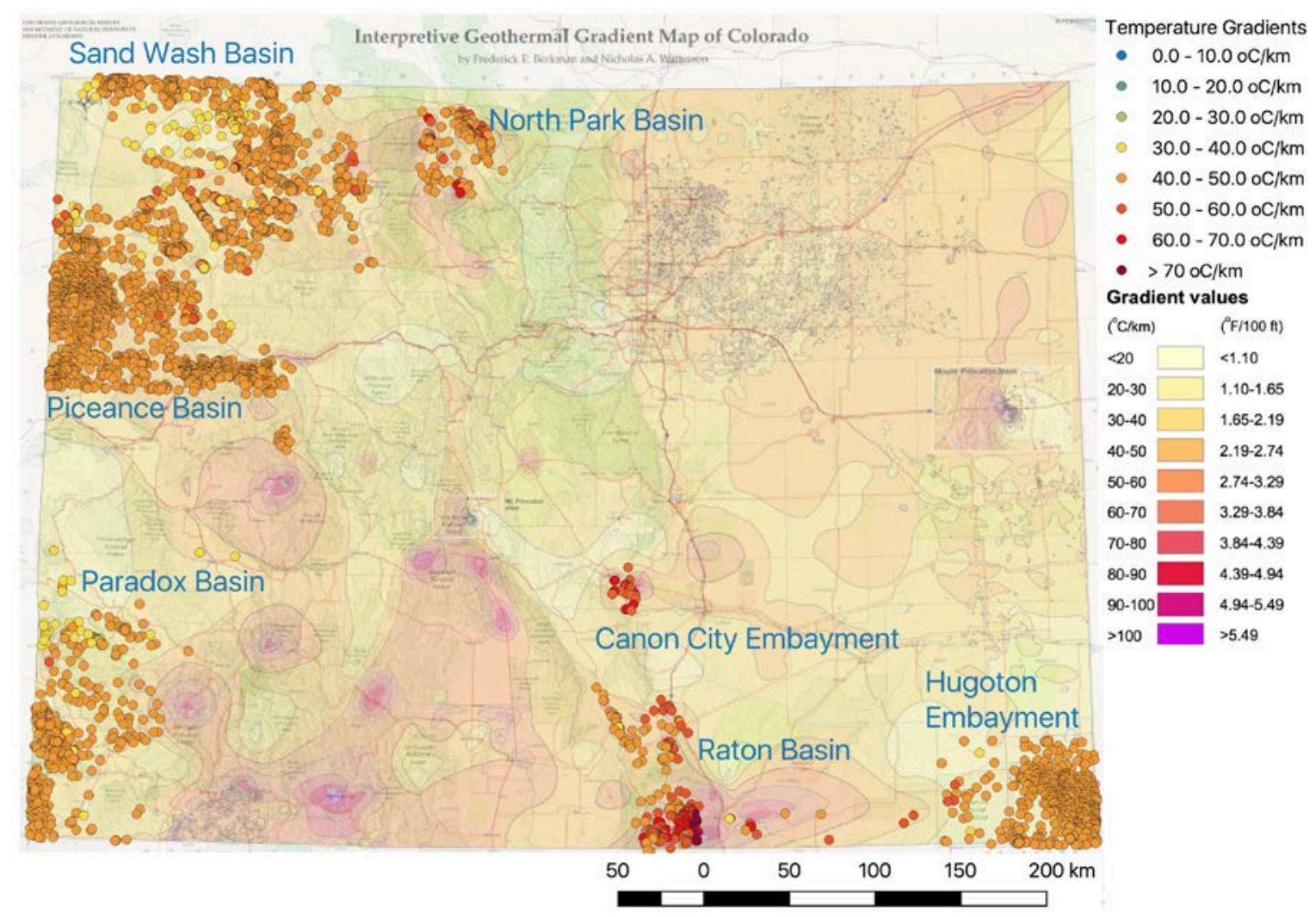

Figure 10. Map of temperature gradient data for the Canon City Embayment, Hugoton Embayment, and North Park, Paradox, Piceance, Raton, and Sand Wash Basins. Calculated temperature gradients (Dixon 2004) are overlain on an interpretive temperature gradient map (Sares, Berkman, and Watteson 2009) for comparison. 


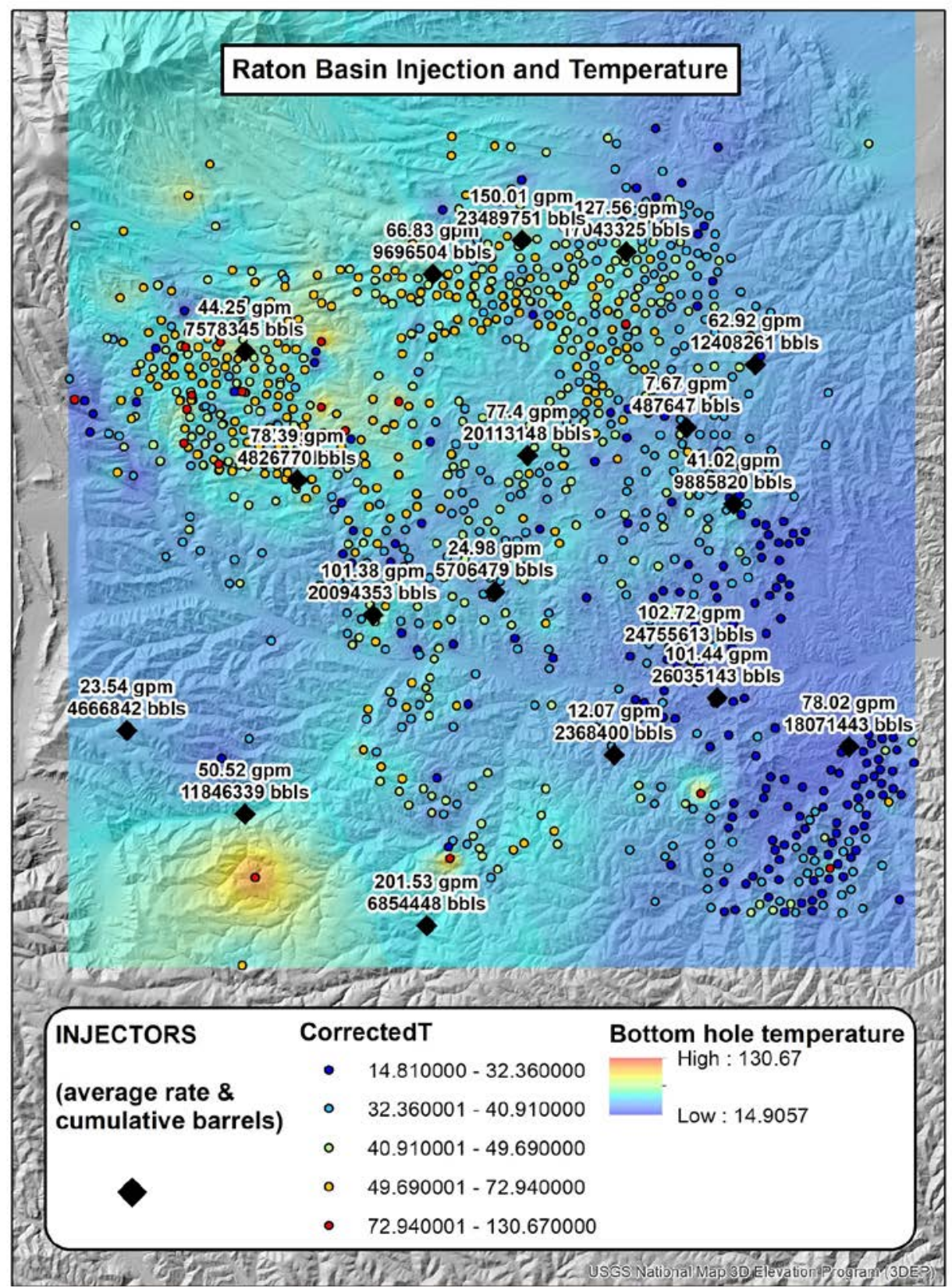

Figure 11. Injection data from Raton Basin wells from the Colorado Oil and Gas Conservation Commission (19 wells with records back to January 1, 1999), plotted with average injection rate (gallons per minute), cumulative injection volume (barrels), and corrected bottom-hole temperature $\left({ }^{\circ} \mathrm{C}\right)$ from the Colorado Geological Survey

\section{Texas}

The Bureau of Economic Geology at the University of Texas at Austin identified geopressuredgeothermal fairways within the Gulf Coast region of Texas (Figure 12). The Wilcox and Frio Formations within these fairways contain geopressured brine saturated with natural gas. One promising area identified by the Bureau of Economic Geology is the Cuero Fault Block within the DeWitt Fairway (Bebout et al. 1982). 
The Wilcox Formation within the Cuero Fault Block has more than $168 \mathrm{~m}$ of geopressured sandstone, measured fluid temperatures of $150^{\circ} \mathrm{C}$ at $3.3 \mathrm{~km}$, and permeabilities ranging from less than 2 to more than $100 \mathrm{mD}$ (Bebout et al. 1982). There are many wells completed in the Wilcox Formation within this fault block (Figure 12). Geologic mapping, data mining, reservoir modeling, and techno-economic analysis could be conducted to evaluate the feasibility of developing this geopressured-geothermal resource. Some expected benefits of developing these geopressured reservoirs include the artesian flow of brine saturated with natural gas and potentially reusable wells and surface infrastructure.
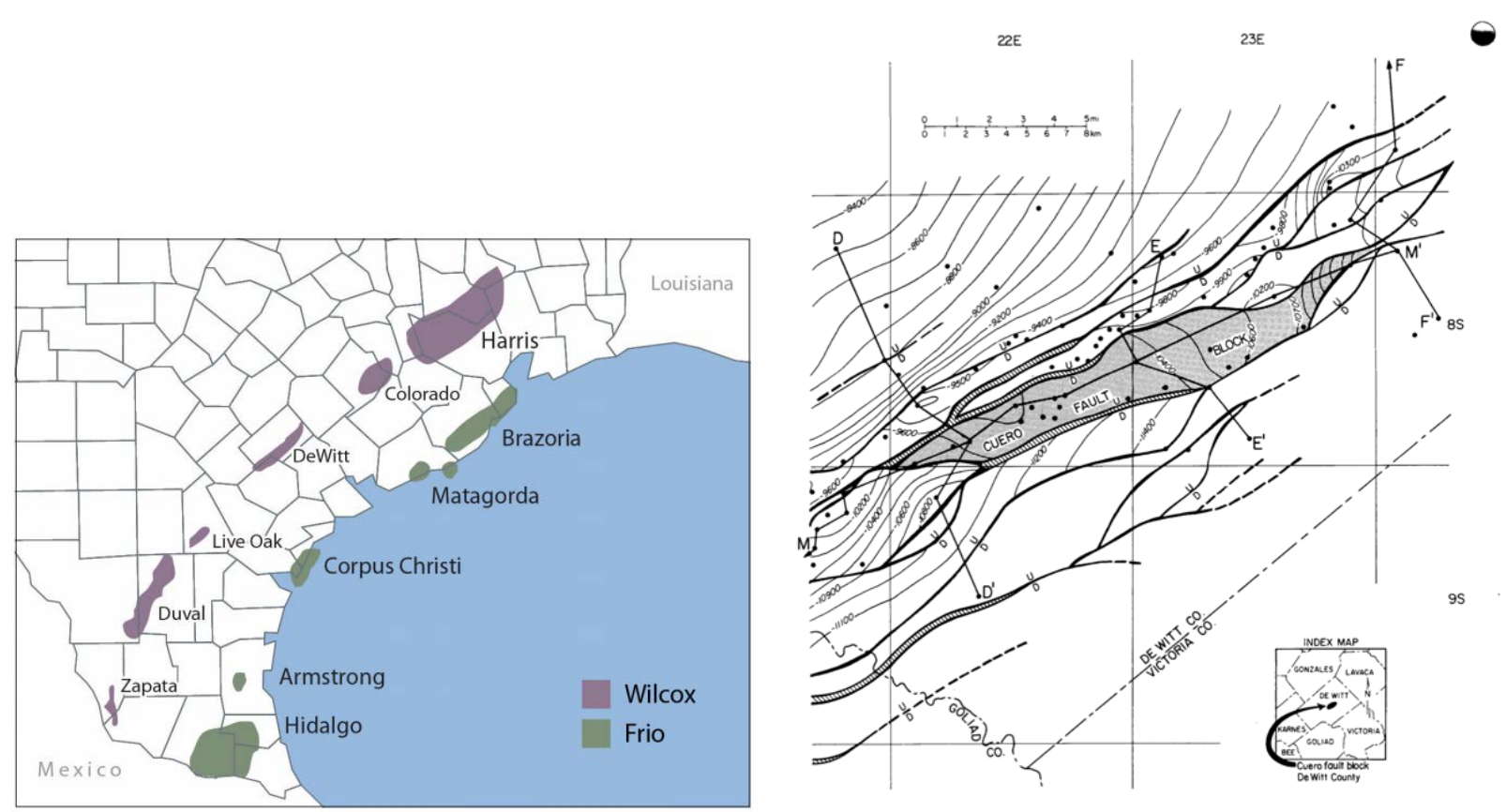

Figure 12. Left Panel: Frio and Wilcox Fairways (Esposito and Augustine 2011). Right Panel: Structure map of Wilcox Formation within the Cuero Fault Block in the DeWitt Fairway (Bebout et al. 1982).

\section{Conclusions and Next Steps}

This study investigated several sedimentary basins across the United States and determined that sedimentary basins in Nevada, Utah, Colorado, and Texas were most prospective for conventional geothermal electricity production. Sedimentary resources in Nevada and Utah are most attractive, followed by tested resources in Texas and untested resources in Colorado. Reservoir modeling and techno-economic analysis were performed at Marys River Basin-North in Nevada. Geothermal energy production at this location is expected to have an LCOE ranging between 10 and 20 cents/kWh. Additional work may result in lower LCOE estimates at this location and other attractive prospects in these three regions.

As a follow-on to this study, three projects are proposed here, one in which the feasibility of conventional geothermal electricity production from sedimentary basins in Nevada and Utah is explored in greater detail. The second and third proposed projects explore the feasibility of lessconventional geothermal developments (e.g., coproduced, direct use, enhanced geothermal systems, advanced geothermal systems) in Colorado and Texas. 


\subsection{Nevada and Utah}

Now that we have an improved understanding of carbonate properties and distribution, a possible follow-up project could be aimed at identifying a potential carbonate geothermal system (CGS) capable of hosting a test site similar to DOE's EGS laboratory at the Frontier Observatory for Research in Geothermal Energy (FORGE). Such a test site is necessary to better understand the geological, geophysical, and reservoir properties, as well as long-term reservoir performance of a CGS. Specifically, the following CGS parameters are of interest:

- Porosity and permeability distribution and depth relationships

- Limestone vs. dolomite host-rock favorability and relationship to produced fluids

- Fracture network properties and patterns

- Productivity/injectivity indices of various lithologies

- Thermal modeling (i.e., the relationship of thermal conductivity to temperature decline in conductive systems)

- Wellbore heat loss based on depth, flow rate, thermal conductivity, etc.

- Non-compressible gas content and importance to reservoir pressure (e.g., high $\mathrm{CO}_{2}$ concentrations as observed in Turkish geothermal systems)

- Scaling potential of reservoir fluids and relative to host rock type (i.e., within the wellbore/surface equipment and in the formation)

- Stimulation potential and techniques

- Alteration potential and characteristics

- Necessary well spacing to prevent short-circuiting and limit thermal decline

- Potential surficial signatures (e.g., reservoir degassing)

- Reservoir heterogeneity (i.e., temperature, permeability, chemistry, pressure)

- Geochemical relationship to thermal springs

- Geophysical signature of saturated vs. unsaturated fractured and unfractured carbonate rock.

The identification of a suitable site would be accomplished through a multidisciplinary exploration campaign consisting of additional data mining, geophysical data purchase and acquisition, regional carbonate mapping, heat flow analysis to reconcile deeper elevated temperatures within an apparent heat flow low, play fairway analysis (PFA), and 3D modeling. Additionally, available well data would be evaluated to identify opportunities for reentering and/or deepening (similar to DOE's Wells of Opportunity initiative) to provide some of the parameters listed above. This effort would likely require university and National Lab collaboration. Because much of the University of Nevada, Reno, PFA project overlaps with the identified carbonate corridor, the techniques developed as part of that effort could be adapted for this proposal.

\subsection{Colorado}

This study investigated a number of sedimentary basins across the United States and determined that sedimentary basins in Nevada and western Utah were most prospective for geothermal electricity production compared to those in Colorado and elsewhere due to temperatures at depth, permeability, and other factors. The focus of the data-mining efforts for this study, therefore, was on Nevada and Utah basins. 
However, the three sedimentary basins in Colorado described above deserve further consideration. While not as hot and potentially not as permeable as the Nevada and Utah basins that were the subject of more detailed study, the three sedimentary basins in Colorado all show promise for direct use (heat) and possibly power generation.

One advantage of Colorado's sedimentary basins is that they are all currently being exploited for oil and gas production. While few of the oil and gas wells penetrate formations identified in this study as geothermal targets, this nevertheless means that (1) there is an abundance of active wells that provide valuable subsurface information, (2) one or more active wells could potentially be deepened for coproduced or hydrothermal fluid production, and/or (3) one or more inactive wells could be repurposed for hydrothermal fluid production only.

Even if permeable reservoirs are not identified, high heat flow in these basins could make them prospective for the application of EGS technologies, where costs could be substantially less than in typical geothermal hard rock environments. The advantages of EGS development in sedimentary basins are described in Allis et al. (2015). Colorado currently does not restrict hydraulic fracturing, so direct transfer of oil and gas techniques could be fully applied to geothermal development on Colorado's sedimentary basins. Augustine and Zerpa (2016) showed that sedimentary geothermal becomes more feasible when considering EGS technologies. Alternatively, a more recently developed geothermal technology involves closed-loop heat extraction in high-heat-flow sedimentary basins, commonly referred to as advanced geothermal systems (AGS), currently being demonstrated in Alberta, Canada (https://eavor.com/technology/). Colorado's high-heat-flow but possibly low-permeability sedimentary basins could be good candidates for testing this technology.

The following sections present a five-part approach to a prefeasibility study of geothermal development in one sedimentary basin in Colorado. This approach will result in the selection of one prospect for geothermal development and evaluate the development model most likely to succeed at that prospect (e.g., direct use only, power-and-heat, power only using conventional or unconventional technologies).

\subsubsection{Exhaustive Data Mining}

The following stratigraphic units have been identified as geothermal target formations:

- Denver Basin: (1) intervals within the "Sussex" and "Dakota" stratigraphic sections, (2) the interval between the Pierre Formation and the top of the Niobrara Formation, (3) the interval between the top of the Dakota to the top of the Permian, and (4) the Lyons Formation, particularly in the Wattenberg Field

- Piceance Basin: the Leadville Limestone Formation

- Raton Basin: the Sangre de Cristo Formation.

Further work would include obtaining well logs, temperature surveys, well flow tests, and pressure transient analyses for these target formations, identifying other target formations not listed here (e.g., Dakota Sands in the Piceance Basin), and performing detailed evaluations of measured parameters for temperature, permeability, and thickness information. 
Augustine and Zerpa (2016) carried out extensive data-mining efforts for the Lyons Formation in the Wattenberg Field and concluded that the feasibility of electricity production from this formation is a function of permeability. Therefore, the focus of this task would be obtaining permeability data for the formations of interest in the Denver Basin.

Some wells in the Piceance Basin have commercial temperature logs available online. These display some variability in downhole thermal gradient (Morgan 2015); however, some intervals have gradients up to $70^{\circ} \mathrm{C} / \mathrm{km}$. This task would examine these logs in the context of geologic and structural data to constrain temperature and permeability extrapolations.

In the Raton Basin, Broadhead (2008) reports that water is produced in oil and gas wells from formations of Pennsylvanian age (deeper than the Sangre de Cristo units), including waterproducing sandstones used as injector formations that have "sufficient porosity and permeability to be a potential water reservoir." This task would mine data (well logs, injectivity data, etc.) for the Sangre de Cristo Formation in the Raton Basin.

\subsubsection{Data Acquisition and Interpretation}

Geophysical data, including seismic data, are available for purchase for all three Colorado sedimentary basins of interest (https://web.seismicexchange.com/1/). For example, reprocessed 2D seismic lines exist across the Raton Basin that could be obtained and used to develop a cross section of the basin. Other detailed structural data from regional geophysical investigations, such as magnetotellurics, gravity, aeromagnetics, etc., may be available for sedimentary basins in Colorado. This phase of work could involve collaboration with outside institutions such as universities to inexpensively acquire additional data sets. For example, the Colorado School of Mines acquires geophysical data for a geothermal site in Colorado each summer as part of their geologic field camp program, and the University of Colorado has expertise in remote-sensing techniques for geologic exploration.

Well cores may be available for some deep wells in the Denver, Piceance, and/or Raton Basins. Should well cores be available for the selected prospect, the National Renewable Energy Laboratory (NREL) could collaborate with the National Energy Technology Laboratory (NETL) to measure the reservoir properties of cores using NETL's state-of-the art rock characterization laboratory. This would be of particular interest for a coproduced geothermal development concept.

Finally, some of the target formations discussed above, such as the Sangre de Cristo Formation in the Raton Basin, are exposed at the surface in adjacent mountain ranges. In this case, field studies of the unit (rock sampling for petrophysical and chemical properties, fracture mapping, etc.) may be undertaken to better understand the formation's reservoir properties. This work could also be performed at NETL's rock characterization laboratory.

\subsubsection{Downselect Prospective Basin}

Based on the results from the first two phases, a simplified PFA approach will be undertaken to determine which of Colorado's three sedimentary basins is the most feasible prospect for geothermal development. Borrowed from the petroleum industry, the PFA technique seeks to reduce risk by defining local areas (plays) that have high potential for hosting geothermal resources, while rejecting larger areas with a higher potential for failure (Garchar et al. 2016). 
Drawing from the PFA method applicable to blind sedimentary plays, data sets will be compiled and statistically analyzed to identify one sedimentary basin (or zone within a sedimentary basin) with the highest probability for hosting a geothermal resource capable of producing power and/or heat.

A parallel study would investigate the potential demand for power and/or direct use near prospective resources to get a preliminary sense of the socioeconomic feasibility of geothermal development at those sites. For example, NREL's Flatirons Campus is situated on the western edge of the Denver Basin, which was recently the focus of a geothermal opportunities study (Warren et al. 2020) that suggested the campus could be a testbed location for sedimentary geothermal technologies such as sedimentary hydrothermal heat-and-power, EGS, AGS, and geothermal storage. On the Flatirons Campus, potential geothermal applications (e.g., heat, electricity, storage) would be integrated with other renewable technologies to aid understanding of how geothermal technologies can support greater penetration of variable renewables. While the Raton and Piceance Basins are more remote, and therefore demand for geothermal heat and power may be more limited, they appear to host geothermal resources that would support a similar suite of technologies.

Other considerations, such as the proximity to existing and planned infrastructure, water availability, etc., will be evaluated in addition to resource factors to determine prospectivity. For example, McDonald et al. (2011) believe the Raton Basin has the potential for geothermal electrical generation at depths as shallow as $1.5 \mathrm{~km}$ due to the high heat flow and thermal gradients; however, they note that scarce water supplies in the area could be an impediment to development. This may be the case for the Denver Basin as well. While this does not eliminate the possibility of geothermal development in those basins, it may make them better candidates for AGS-type closed-loop technologies that do not require large amounts of water.

\subsubsection{Conceptual Subsurface Modeling}

The crustal heat anomaly responsible for the high geothermal gradients in Colorado sedimentary basins has not been well constrained, nor has the role of fracturing and faulting in the permeability of target formations. This task would evaluate the geologic mechanisms potentially responsible for anomalous heat flow in Colorado sedimentary basins such as: (1) the role of the epithermal activity associated with the Colorado Mineral Belt; (2) the role of batholith emplacement; (3) the role of radiogenic heat flux associated with anomalous $\mathrm{U}$, Th, and $\mathrm{K}$ concentrations in plutons and/or epithermal deposits; and (4) the role of crustal thinning and/or magmatic input related to Quaternary volcanic activity along the southern edge of the Colorado Plateau (this applies only to the Raton Basin).

Conceptual modeling of the hydrothermal system in the selected Colorado sedimentary basin would emphasize key questions about heat transfer (e.g., are these systems purely conductively heated aquifers or is there an element of convective fluid flow?) and permeability controls (e.g., matrix porosity vs. fracture permeability vs. karst permeability in carbonates, role of major fault zones). The conceptual model will be used to estimate or calculate key reservoir parameters or the next task (i.e., pre-feasibility study including a techno-economic analysis of proposed development model). 


\subsubsection{Geothermal Development Pre-Feasibility Study}

Once resource parameters are obtained from the first four phases, a preliminary techno-economic study would be completed for the selected prospect and development model. In addition, sitespecific ownership laws, rules, and regulations would have to be reviewed. While Colorado may have a regulatory environment favorable for EGS due to its allowance of hydraulic fracturing, as of 2019 the socioeconomic feasibility of geothermal power development in Colorado remains untested due to the lack of existing geothermal power plants in the state. Colorado classifies geothermal fluids as water on private land and as a mineral on state and federal land, but rules and regulations concerning geothermal power production are not well defined (Morgan 2012).

Additional studies may include induced seismicity risk of EGS techniques, heat demand and levelized cost of heat (LCOH) calculations, reservoir modeling study of AGS-type closed-loop application, and other analyses. The outcome of this final step will be a pre-feasibility study of a particular development model of a selected sedimentary geothermal prospect in Colorado.

\subsection{Texas}

Birney, Jones, and Webber (2019) assessed the feasibility of using a geothermal multi-effect distillation (MED) plant to produce fresh water from brackish aquifers in Texas. They found this water treatment approach to be potentially viable in the Frio and the Wilcox Fairways. They analyzed the use of geothermal electricity generation to power the desalination process (Figure 13). Their work indicates that a single well could produce $121-1,132 \mathrm{~m}^{3} /$ day of fresh water, enough to supply $232-2,133$ people.

One promising geothermal resource identified by the Bureau of Economic Geology is the DeWitt Fairway's Wilcox Formation within the Cuero Fault Block (Bebout et al. 1982). There are many oil and gas wells completed in the Wilcox Formation within this fault block, which contains hydrocarbons above thick brackish aquifers. A feasibility study could evaluate the exploitation of this developed resource for multi-effect distillation and membrane desalination processes. The potential study would include techno-economic analysis. In the first phase, geologic mapping, data mining, and reservoir modeling tasks would assess the utilization of existing wells and their production potential. In the second phase, multiple desalination processes would be evaluated for technical feasibility. The final phase includes techno-economic analyses and a final report. 


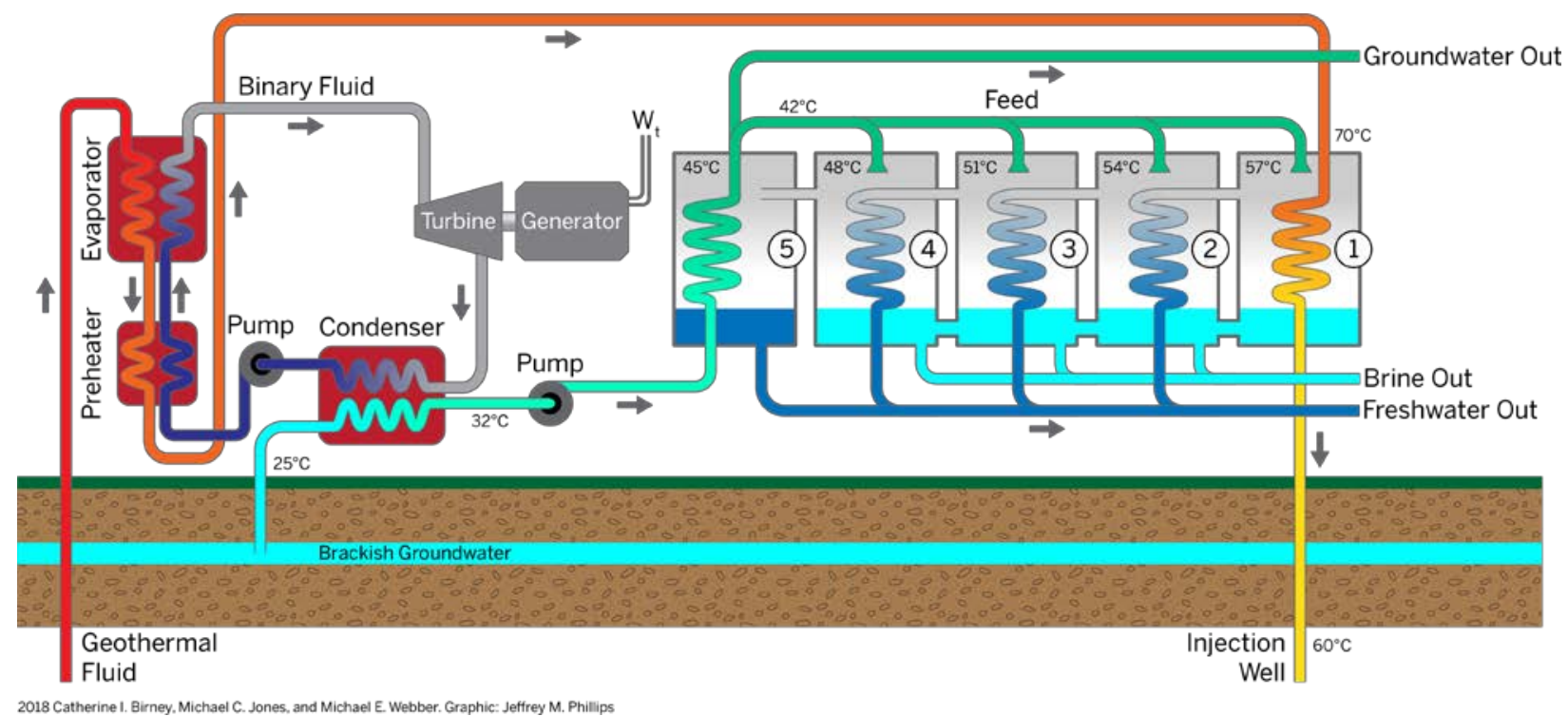

Figure 13. Schematic of combined binary cycle multi-effect distillation plant used to generate electricity and desalinate brackish groundwater. Generated electricity is used to power the system pumps.

Source: Birney, Jones, and Webber 2019 


\section{References}

Abbott, David M. and David C. Noe. 2002. "The Consequences of Living with Geology: A Model Field Trip for the General Public.” Geological Society of America Field Guides 3: 1-16. https://doi.org/10.1130/0-8137-0005-1.185.

Allis, Rick, Joe Moore, Bob Blackett, Mark Gwynn, Stefan Kirby, and Douglas Sprinkel. 2011. "The Potential for Basin-Centered Geothermal Resources in the Great Basin." GRC Transactions 35: 683-688.

https://geology.utah.gov/docs/geothermal/ngds/supplemental/reports/GRCv35 Allis etal.pdf.

Allis, Rick, Joseph N. Moore, Tom Anderson, Milind Deo, Stefan Kirby, Richard Roehner, and Thomas Spencer. 2013. "Characterizing the Power Potential of Hot Stratigraphic Reservoirs in the Western U.S." Proceedings 38th Workshop on Geothermal Reservoir Engineering, Stanford University, Stanford, CA, 11-13 February 2013.

https://pangea.stanford.edu/ERE/pdf/IGAstandard/SGW/2013/Allis.pdf.

Allis, Rick, Mark Gwynn, Christian Hardwick, Greg Mines, and Joseph Moore. 2015. "Will Stratigraphic Reservoirs Provide the Next Big Increase in U.S. Geothermal Power Generation?" GRC Transactions 39: 389-398.

https://pdfs.semanticscholar.org/6342/8f699e7e9d37e30dbcdffc3fa4f1ce3192a8.pdf.

Augustine, Chad. 2014. "Analysis of Sedimentary Geothermal Systems Using an Analytical Reservoir Model.” GRC Transactions 38: 641-648. http://pubs.geothermallibrary.org/lib/grc/1033602.pdf.

Augustine, Chad and Luis Zerpa. 2016. Sedimentary Geothermal Feasibility Study. Golden, CO: National Renewable Energy Laboratory. NREL/SR-6A20-66552.

https://www.nrel.gov/docs/fy17osti/66552.pdf.

Bebout, Don G., Zaki Bassiouni, Dale R. Carver, C. G. Groat, Adrian E. Johnson, Jr., and Fred M. Wrighton. 1982. Technical Support for Geopressured-Geothermal Well Activities in Louisiana. Baton Rouge, LA: Louisiana Geological Survey. DOE/NV/10174-2. https://www.osti.gov/servlets/purl/6525038-mHkTtb/native/.

Beckers, Koenraad F. and Kevin McCabe. 2019. "GEOPHIRES v2.0: Updated Geothermal Techno-Economic Simulation Tool.” Geothermal Energy 7 (5). https://link.springer.com/article/10.1186/s40517-019-0119-6.

Birney, Catherine I., Michael C. Jones, and Michael E. Webber. 2019. “A Spatially Resolved Thermodynamic Assessment of Geothermal Powered Multi-Effect Brackish Water Distillation in Texas." Resources 8 (2): 65. https://www.mdpi.com/2079-9276/8/2/65.

Bohlen, K. 2012. "Preliminary Geothermal Resource Assessment for the Raton Basin, Colorado." GRC Transactions 36: 1327-1334. http://pubs.geothermallibrary.org/lib/grc/1030403.pdf. 
Broadhead, Ronald F. 2008. The Natural Gas Potential of North-Central New Mexico: Colfax, Mora and Taos Counties. Socorro, NM: New Mexico Bureau of Geology and Mineral Resources. OF 510. https://geoinfo.nmt.edu/publications/openfile/downloads/500599/510/OFR $\% 20510 \% 20$ Natural\%20gas\%20in\%20north-central\%20NM.pdf.

Chapin, C. E. 2012. "The Origin of the Colorado Mineral Belt.” Geosphere 8 (1): 28-43. https://doi.org/10.1130/GES00694.1.

Computer Modelling Group, Ltd. (CMG). 2019. “CMG STARS, version 2019.10.” Calgary, AB. https://www.cmgl.ca/.

Coolbaugh, M.F., G. B. Arehart, J. E. Faulds, and L. J. Garside. 2005. “Active Geothermal Systems and Associated Gold Deposits in the Great Basin.” GRC Transactions 29: 215-221. http://pubs.geothermal-library.org/lib/grc/1022596.pdf.

Crowell, Anna M., Aaron T. Ochsner, and Will Gosnold. 2012. "Correcting Bottom-Hole Temperatures in the Denver Basin: Colorado and Nebraska." GRC Transactions 36: 201-206. http://pubs.geothermal-library.org/lib/grc/1030229.pdf.

Crowell, Anna M. and Will Gosnold. 2013. "GIS-based Geothermal Resource Assessment of the Denver Basin: Colorado and Nebraska." GRC Transactions 37: 941-944. http://pubs.geothermallibrary.org/lib/grc/1030684.pdf.

Curtis, B. F. 1988. "Sedimentary Rocks of the Denver Basin." Sedimentary Cover - North American Craton D-2: 182-196. https://doi.org/10.1130/DNAG-GNA-D2.

Deo, Milind, Richard Roehner, Rick Allis, and Joseph Moore. 2014. "Modeling of Geothermal Energy Production from Stratigraphic Reservoirs in the Great Basin." Geothermics 51: 38-45. https://doi.org/10.1016/j.geothermics.2013.10.011.

Dettinger, M. D. and Donald H. Schaefner. 1996. "Hydrogeology of Structurally Extended Terrain in the Eastern Great Basin of Nevada, Utah, and Adjacent States, from Geologic and Geophysical Models." Hydrologic Atlas 694. https://doi.org/10.3133/ha694D.

Dettinger, M. D., J. R. Harrill, D. L. Schmidt, and J. W. Hess. 1995. Distribution of CarbonateRock Aquifers and the Potential for their Development, Southern Nevada and Adjacent Parts of California, Arizona, and Utah. Carson City, NV: U.S. Geological Survey. Water-Resources Investigations Report 91-4146. https://doi.org/10.3133/wri914146.

Dixon, J. 2004. Evaluation of Bottom-Hole Temperatures in the Canon City Embayment, Hugoton Embayment, North Park, Paradox, Piceance, Raton, and Sand Wash Basins of Colorado. Golden, CO: Colorado Geological Survey. OF-04-01. https://coloradogeologicalsurvey.org/publications/evaluation-bottom-hole-temperature-canoncity-north-park-paradox-piceance-raton-sand-wash-basins/.

Esposito, Ariel and Chad Augustine. 2011. "Geopressured Geothermal Resource and Recoverable Energy Estimate for the Wilcox and Frio Formations, Texas." GRC Transactions 35: 1563-1572. http://pubs.geothermal-library.org/lib/grc/1029455.pdf. 
Garchar, Laura, Alex Badgett, Angel Nieto, Kate Young, Eric Hass, and Mike Weathers. "Geothermal Play Fairway Analysis: Phase I Summary." Proceedings 41st Workshop on Geothermal Reservoir Engineering, Stanford University, Stanford, CA, 22-24 February 2016. https://pangea.stanford.edu/ERE/pdf/IGAstandard/SGW/2016/Garchar.pdf.

Geldon, Arthur L. 1989. Ground-Water Hydrology of the Central Raton Basin, Colorado and New Mexico. U.S. Geological Survey Water-Supply Paper 2288.

https://pubs.usgs.gov/wsp/2288/report.pdf.

Gwynn, Mark, Rick Allis, Doug Sprinkel, Robert Blackett, and Christian Hardwick. 2014. "Geothermal Potential in the Basins of Northeastern Nevada." GRC Transactions 38: 10291040. http://pubs.geothermal-library.org/lib/grc/1033654.pdf.

Heilweil, Victor M. and Lynette E. Brooks. 2011. Conceptual Model of the Great Basin Carbonate and Alluvial Aquifer System. USGS Scientific Investigations Report 2010-5193. https://pubs.usgs.gov/sir/2010/5193/PDF/SIR2010-5193.pdf.

Higley, Debra K. 1988. Core Porosity, Permeability, and Vitrinite Reflectance Data from the Lower Cretaceous J Sandstone in 141 Denver Basin Coreholes. U.S. Geological Survey OF 88527-A. https://doi.org/10.3133/ofr88527A.

Hulen, Jeffrey B. 1991. Investigation of High-Temperature, Igneous-Related Hydraulic Fracturing as a Reservoir Control in the Blackburn and Grant Canyon/Bacon Flat Oil Fields, Nevada. Earth Sciences Lab, University of Utah Research Institute. DOE/ER/14133-1. https://www.osti.gov/servlets/purl/5790120.

Hulen, Jeffrey B., Fraser Goff, Joseph R. Ross, Louis C. Bortz, and S. Robert Bereskin. 1994. "Geology and Geothermal Origin of Grant Canyon and Bacon Flat Oil Fields, Railroad Valley, Nevada." The American Association of Petroleum Geologists Bulletin 78: 596-623. https://www.osti.gov/biblio/6899385-geology-geothermal-origin-grant-canyon-bacon-flat-oilfields-railroad-valley-nevada.

Hulen, Jeffrey B., S. Robert Bereskin, and Louis C. Bortz. 1990. "High-Temperature Hydrothermal Origin for Fractured Carbonate Reservoirs in the Blackburn Oil Field, Nevada." The American Association of Petroleum Geologists Bulletin 74: 1262-1272. https://doi.org/10.1306/0C9B2489-1710-11D7-8645000102C1865D.

Masbruch, Melissa D., Victor M. Heilweil, and Lynette E. Brooks. 2012. "Using Hydrogeologic Data to Evaluate Geothermal Potential in the Eastern Great Basin." GRC Transactions 36: 4752. http://pubs.geothermal-library.org/lib/grc/1030209.pdf.

McDonald, Mark R., Will Gosnold, Hossein Salehfar, Michael Mann, Kirtipal Barse, Samir Dahal, Anna Crowell, et al. 2011. Evaluation of Geothermal Potential for Selected Resources in the Rio Grande Rift: Colorado and New Mexico. Technical report by the University of North Dakota Geothermal Laboratory to the National Renewable Energy Laboratory; Contract No. AXH-1-40456-01, 180 pp. Report not available online. 
Moeck, Inga S. 2014. "Catalog of Geothermal Play Types Based on Geologic Controls." Renewable and Sustainable Energy Reviews 37: 867-882.

https://doi.org/10.1016/j.rser.2014.05.032.

Moore, Joseph, and Rick Allis. 2016. Novel Geothermal Development of Deep Sedimentary Systems in the United States. Final Technical Report. GTO Project Award Number DEEE0005128. https://www.osti.gov/servlets/purl/1399014.

Morgan, Paul. 2009. "A Preliminary Analysis of Geothermal Resources in the Central Raton Basin, Colorado, from Bottom-Hole Temperature Data." GRC Transactions 33: 509-513. http://pubs.geothermal-library.org/lib/grc/1028509.pdf.

Morgan, Paul. 2012. "Geothermal Regulations in Colorado-Land Ownership is the Key." GRC Transactions 36: 1233-1238. http://pubs.geothermal-library.org/lib/grc/1030389.pdf

Morgan, Paul. 2015. "Sedimentary Basin Geothermal Resources in the Piceance Basin, Colorado." GRC Transactions 39: 1049-1056. http://pubs.geothermallibrary.org/lib/grc/1032253.pdf.

Morgan, Paul, Matt Sares, and Marieke Dechesne. 2009. "Stratigraphic Control of Temperatures in the Wattenberg Field, Denver Basin, Colorado." Colorado Geological Survey. http://www.searchanddiscovery.com/documents/2009/80066morgan/ndx morgan.pdf.

Muffler, L. J. P. 1978. Assessment of Geothermal Resources of the United States-1978. U.S. Geological Survey Circular 790. https://pubs.usgs.gov/circ/1979/0790/report.pdf.

Porro, Colleen, Ariel Esposito, Chad Augustine, and Billy Roberts. 2012. "An Estimate of the Geothermal Energy Resource in the Major Sedimentary Basins in the United States." GRC Transactions 36: 1359-1370. http://pubs.geothermal-library.org/lib/grc/1030408.pdf.

Porro, Colleen and Chad Augustine. 2012. Estimate of Geothermal Energy Resource in Major U.S. Sedimentary Basins. Golden, CO: National Renewable Energy Laboratory. NREL/PR6A20-55017. https://www.nrel.gov/docs/fy12osti/55017.pdf.

Sares, M., F. Berkman, and N. Watteson. 2009. "Statewide geothermal resource mapping in Colorado." Transactions - Geothermal Resources Council 33.

Sass, J. H., A. H. Lachenbruch, R. J. Munroe, G. W. Green, and T.H. Moses, Jr. 1971. "Heat flow in the western United States.” J. Geophys. Res. 76: 6356-6431.

Simmons, Stuart, Rick Allis, Joe Moore, Mark Gwynn, Christian Hardwick, Stefan Kirby, and Phil Wannamaker. 2017. "Conceptual Models of Geothermal Resources in the Eastern Great Basin." Proceedings 42nd Workshop on Geothermal Reservoir Engineering, Stanford University, Stanford, CA, 13-15 February 2017. https://pangea.stanford.edu/ERE/pdf/IGAstandard/SGW/2017/Simmons.pdf. 
Tester, Jefferson W., Brian J. Anderson, Anthony S. Batchelor, David D. Blackwell, Ronald DiPippo, Elisabeth M. Drake, John Garnish, et al. 2007. "Impact of Enhanced Geothermal Systems on US Energy Supply in the Twenty-First Century." Philosophical Transactions of the Royal Society 365: 1057-1094. https://doi.org/10.1098/rsta.2006.1964.

Topper, R., K. Scott, and N. Watterson. 2011. Geologic Model of the Purgatoire River Watershed within the Raton Basin, Colorado. Colorado Geological Survey.

Warren, I., A. Kolker, N. Taverna, and K. Young. 2020. NREL Flatirons Campus Geothermal Opportunities Assessment: Proposed Contributions to Integrated Energy Systems at Scale. Golden, CO: National Renewable Energy Laboratory. NREL/MP-5500-75302. https:/highpoint.nrel.gov/sites/iop/Documents/gen/fy20/75302.pdf.

Watts, K. R. 2006. Hydrostratigraphic framework of the Raton, Vermejo, and Trinidad aquifers in the Raton Basin, Las Animas County, Colorado. U.S. Geological Survey Scientific Investigations Report 2006-5129. https://pubs.usgs.gov/sir/2006/5129/pdf/SIR06-5129_508.pdf. 